\title{
PODBLIGHT OF THE LIMA BEAN CAUSED BY
} DIAPORTHE PHASEOLORUM

L. L. HARTER

\section{Reprinted from JOURNAL OF AGRICULTURAL RESEARCH}

Vol. XI, No. $10: \quad:$ Washington, D. C., December 3,1917

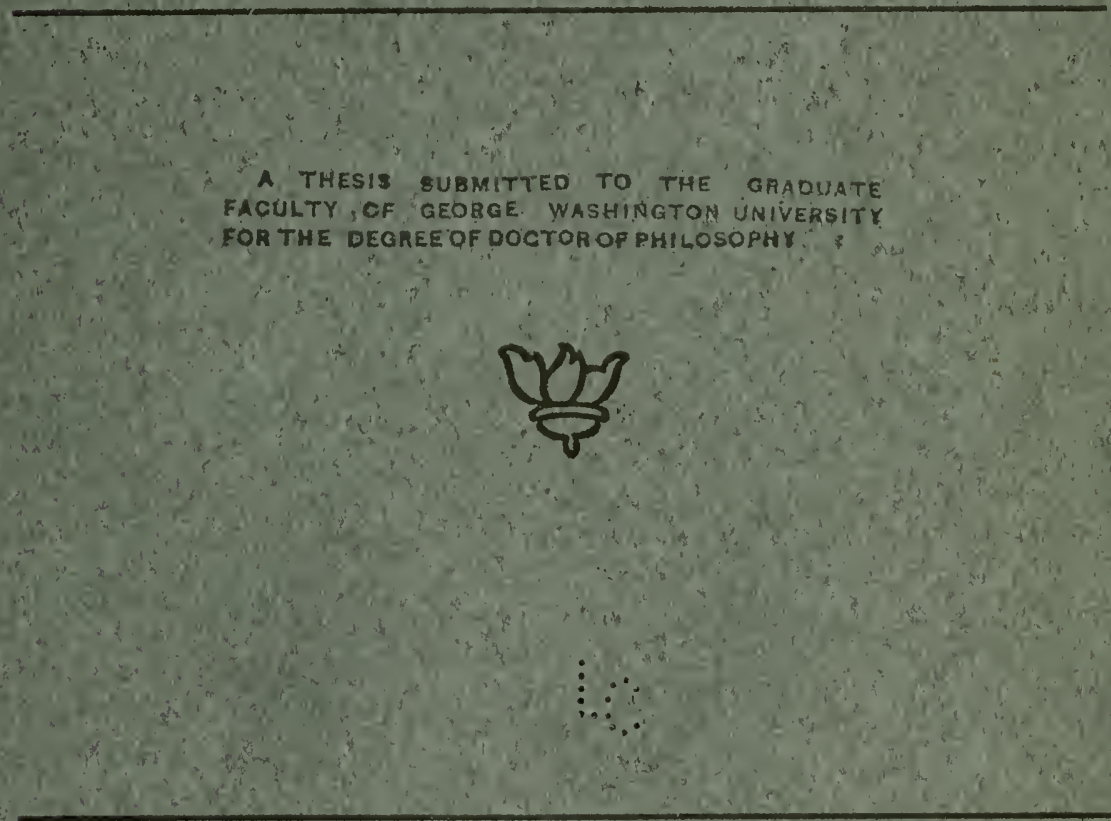

PUBLISHED BY AUTHORITY OF THE SECRETARY OF AGRICULTURE, WITH THE COOPERATION OF THE ASSOCIATION OF AMERICAN AGRICULTURAL COLLEGES AND EXPERIMENT STATIONS : 



\title{
PODBLIGHT OF THE LIMA BEAN CAUSED BY DIAPORTHE PHASEOLORUM
}

\author{
BY L. L. HARTER, \\ Pathologist, Cotton, Truck, and Forage Crop Disease Investigations, Bureau of Plant \\ Industry, United States Department of Agriculture

\section{INTRODUCTION}

The Lima bean (Phaseolus lunatus L.), compared with some of the other truck crops, is relatively unimportant from a commercial standpoint. It is grown in a small way in the garden by nearly every farmer, and on a commercial scale in a few sections of the United States, particularly along the Atlantic seaboard and along the Pacific coast. Like many other crops grown only for home use or on a commercial scale in a limited area, its several pests and diseases have either been overlooked or ignored. The Lima bean, however, has its share of diseases, some of which have been fairly well studied, while little is known about others. To the latter class belongs the podblight, a disease of considerable economic importance some seasons in commercial fields. It was first discovered by Halsted $(16)^{1}$ in 1891 , in New Jersey. Further than this nothing is known as to the time and place of the origin of the disease.

There is no evidence from the search of the literature that the disease occurs outside of the United States, although it is impossible to state definitely that it does not, in view of the great number of species of Phoma, Phyllosticta, and closely related genera under which the casual fungus may have been described. A careful search through the descriptions of species of the genera Phoma, Phyllosticta, and Phomopsis on different species of Phaseolus has revealed none located in foreign countries identical with the organism causing the podblight. It therefore appears safe to assume at the present time that the disease is indigenous to the United States.

To judge from published accounts, Halsted $(I 6)$ was the first to recognize this disease and found it causing much damage to the pods of pole Lima beans in New Jersey in the fall of $\mathrm{r} 89 \mathrm{r}$. He attributed it to a species of Phyllosticta, pointing out at the same time that large blotches were also produced on the leaves. That he studied the disease with some care and did not content himself with a few passing observations is evident from the fact that he found that the seeds from infected pods, when placed under a suitable environment, such as between moist cloths or paper, developed the fruiting bodies of the fungus.

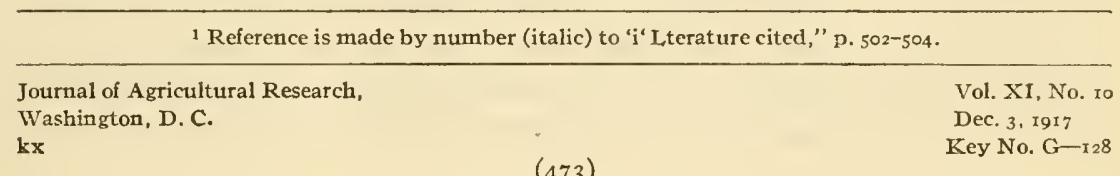


In I $_{992}$ Ellis and Everhart (I 5, p. I 58) evidently collected the same organism on the pods of Phaseolus lunatus at Newfield, N. J., and described it as a new species of Phoma, Phoma subcircinata, pointing out that it differed from Phoma leguminum West. in the subcircinate arrangement of the pycnidia and the rather larger binucleate sporules. Halsted later apparently concurs with Ellis and Everhart that this is a new species of Phoma, for in I 901 he $(I 7)$ refers to the disease again by that name and enlarges his earlier description. Two illustrations are appended to his article, one showing the characteristic appearance of the disease on the pods and the other on the leaves, both typical of the trouble as we know it at the present time.

\section{DISTRIBUTION, PREVAIENCE, AND LOSS}

For 14 years after this disease was found in New Jersey it had either not appeared in any other State or had not been discovered. In 1905, however, Clinton $(5, p, 265)$ reports a leafspot of Phaseolus lunatus at New Haven, Conn., apparently the same as that described and illustrated by Halsted. He states that he did not observe the disease on the pods, but adds that it had not been looked for there. Although agreeing macroscopically with Halsted's description of the disease on the leaves, Clinton entertained some doubt of its identity with Phoma subcircinata $\mathrm{E}$. and $\mathrm{E}$. because of the fact that the spores averaged larger ( 5 to 12 by 2.5 to $3.5 \mu$ ) and were occasionally septate. He suggests the possibility that the fungus may be Ascochyta phaseolorum Sacc.

In 1912 Cook $\left(6, p \cdot 5^{I} 7-5 I 8\right)$ reports a severe outbreak of a disease of pole Lima beans in the State of New Jersey caused by Phyllosticta sp., which occurs on leaves and to some extent on the pods and stems. The following year it was less severe $(7, p .80 I)$, but in I9I 4 he $(8, p .472)$ reports the disease again as causing much damage, attributing it to Phoma subcircinata E. and E. A leafspot caused by Phyllosticta phaseolina Sacc. was also commonly met with.

In view of the relatively few times this disease has been reported during a period of 25 years, it is evident that it has generally been either overlooked or disregarded. This is probably due to the fact that the crop is relatively a minor one and that the disease appears usually after the low prices do not justify further pickings. It, however, is much more widely distributed than the published reports indicate. It was reported (unpublished) to the Plant Disease Survey from one locality in North Carolina by R. H. Fulton in I913. The writer received and studied specimens of badly infected plants from Maryland in I9I 4 and 1915, and from Virginia in 1915. During the seasons of 1914 and 1915 the disease also caused heavy loss to the crop in New Jersey. In conclusion, it may be stated that the disease is rather widely distributed along the Atlantic seaboard and causes considerable damage to the crop.

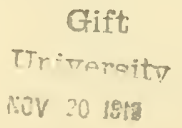




\section{DESCRIPTION OF PODBLIGHT}

Although the ascogenous stage of this fungus has been connected by the writer with the pycnidial stage, the latter is alone concerned in the injury to the crop in the field. A macroscopic description of this disease therefore will be confined to the pycnidial or imperfect stage. In the field under suitable conditions the disease first appears on the leaves of plants from I to 2 feet high. Wet weather is conducive to the spread and warm weather promotes the development of this as well as many other diseases of this type. Serious outbreaks have often occurred immediately following a few days of rainy, warm weather in fields where previously the disease was scarcely noticeable. In such a case the loss is often serious; but if dry weather follows new growth of leaves and fruit will be produced comparatively free of the disease. If, however, the weather continues wet, a new outbreak is liable to occur.

The leaves function as host for the fungus during the earlier part of the season, from which it spreads later to the pods. Large, subcircular, brown, often bordered patches are produced on the leaves (P1. 42, A). These patches, varying in size naturally with age, often attain a diameter of $\mathrm{I}$ to $3 \mathrm{~cm}$. Infection is not restricted to any portion of the leaflets but the regions bordering the midrib are most frequently attacked. The fungus spreads more or less in all directions from the point of infection, but may often be delimited by a large vein or midrib. In this moribund tissue, or in tissue soon after it is killed, the fruiting bodies (pycnidia) of the fungus break through the epidermis. They are arranged more or less concentrically, and appear first as gray or grayish raised pimples, which later darken and become nearly black. They therefore may be seen as conspicuous, minute black specks on the upper surface of the leaves standing apart, sometimes confluent, on a brown background. The dead tissues finally become dry and fall out, leaving a ragged hole.

This disease must not be confused with a leafspot of Lima beans and other varieties of beans, as well as of cowpeas, caused by Phyllosticta phaseolina Sacc., the spots of which are smaller, more nearly round, and the pycnidia smaller and fewer in number.

The disease appears on the pods usually the latter part of July or early in August, at a time when the vines have nearly reached their full development. Under field conditions it is not certain at what stage in the development of the pod infection takes place. Young pods are rarely found diseased, and inoculation experiments have shown that they are infected less easily than ones nearly matured. The disease progresses rather slowly, requiring a week or so days after inoculation to produce a spot of any size or for the production of pycnidia. The growth of a bean pod is comparatively rapid, and it is likely that infection may take place when the pods are young, the fungus becoming visible as the pod approaches maturity. Infection occurs at any point on the surface of the 
pod, but more frequently at or near the ventral suture (P1. 42, B). If infection occurs near or at the dorsal or ventral suture, the fungus spreads in all directions in a circular or semicircular manner, the hyphæ growing among the cells of the pod below the epidermis. The extent of the hyphal growth of the fungus among the cells is indicated by the darkening of the pod above the invaded area, evidently the first signs of the exhaustion of the food supply and approaching death of that part of the pod. This is soon followed by numerous, minute elevations over the surface, the points where the pycnidia are forming. These lifted points are at first gray, but as soon as the pycnidia break through the epidermis they become nearly black and protrude in a domelike manner from the surface. They are often, though not always, arranged concentrically and stand apart; or two or more may be confluent in a cluster or chainlike manner. Upon the death of the pod the fungus grows rapidly through the tissues, the pycnidia breaking out more or less over the entire surface (P1. 42, C). The fruiting bodies which are formed subsequent to the death of the pod are usually not formed concentrically.

Under field conditions the fruiting bodies of the fungus are often found on the dead and more rarely on moribund stems. It is exceedingly uncommon to find typical infections of living stems, and the writer has never been able to produce infection of living stems artificially. The pycnidia, however, appear abundantly after the death of the vine on stems that have been sprayed with spores of the fungus.

The disease is much more common and destructive on the pole Lima beans than on the bush Limas.

\section{ETIOLOGY}

The podblight of Phaseolus lunatus is caused by a fungus pathogen to which various names have been given at different times. The use of different names is largely due to the lack of a knowledge of the life history of the fungus and to the practice of many mycologists in separating the genera Phyllosticta and Phoma, respectively, according to whether the fungus occurs on the leaf, or on the stem, or on other parts of the host.

Halstead ( 16 ) first reported this disease in 1891 as causing considerable damage to the pods and leaves, and attributed it to a species of Phyllosticta. He was evidently in doubt as to the species, for he does not refer it to Phyllosticta phaseolina Sacc. (30, p. I49), which had been described some years earlier and which occurs commonly on Lima beans, on Phaseolus diversifolius, Kansas (Kellerman), New Jersey (Eilis), Canada (Dearness) on Phaseolus perennis, Missouri (Galloway) and on cowpea, Kansas (D. B. Swingle). In 1905 Smith (33) proved the pathogenicity of this organism on the leaves of Lima beans and other varieties, such as kidney and wax, and on cowpeas. He found that the pods were not affected. 
That the writer has been working with the same fungus which Ellis and Everhart described as Phoma subcircinata there is little doubt. Material, collected by Dr. J. B. Ellis at Newfield, N. J., and identified by him as Phoma subcircinata, has been examined and found to be identical with material collected at Vineland, N. J., only 4 miles distant from Newfield. It should be mentioned in this connection that the material from which Ellis and Everhart made their description was likewise collected at Newfield, in 1892. In 1890 , three years before Ellis and Everhart's description of Phoma subcircinata appeared ( $\left.I_{5}, p . I_{5} 8\right)$, Ellis collected and identified as Phyllosticta phaseolina some material from Newfield which upon examination the writer has found to be identical with material later identified by him (Ellis) as Phoma subcircinata and also identical with the material the writer has been studying.

Phoma subcircinata E. and E. was described by Ellis and Everhart $\left(I 5, p . I_{5}\right)$ as follows:

On pods of Lima Beans, Newfield, New Jersey, October, I8gz.

Perithecia subcuticular, 70-90 $\mu$ diam., sublenticular, subconfluent pierced above, membranous, black, subcircinately arranged in large ( $\mathrm{r} \mathrm{cm}$.); round, faintly zonate spots, finally spreading and occupying the entire surface of the pods. Sporules oblong-elliptical, hyaline, 2 -nucleate, $5^{-6}$ by $2-2.5 \mu$, on simple basidia rather larger than the sporules.

This description fits perfectly the fungus the writer has been studying, with the exception of the size of spores and pycnidia. An examination of the material collected and identified by Ellis as Phoma subcircinata shows the spores to be somewhat larger ( 6.4 to 8 .o by 2.4 to $3.6 \mu$, average 7.4 by $2.95 \mu$ ), and the pycnidia considerably larger ( 142 to $276 \mu$, average I $85.8 \mu$ ). Material collected and identified by Ellis three years earlier as Phyllosticta phaseolina and which he probably later took for Phoma subcircinata, bore spores ( 6.0 to 8.0 by 2.8 to $3.2 \mu$, average 7.2 by $2.88 \mu$ ) and pycnidia (I 97.5 to $260.0 \mu$, average 2 I $9.0 \mu$ ) of about the same size. On material which the writer has collected and from which isolations have been made for inoculation work the spores varied from 6.0 to 8.6 by 2.4 to $4.1 \mu$, average 7.50 by $3.23 \mu$, and the pycnidia from 158.0 to $475.0 \mu$, average $245.86 \mu$. From the data at hand it appears evident that the fungus described by Ellis and Everhart as Phoma subcircinata is the same as the one the writer has been studying.

In view of the fact that the fungus causing podblight has been connected with a perfect stage, the genus to which the imperfect form should properly belong is of no great consequence, but it may be of interest to know that this fungus, like a number of others which have been classed as Phoma, belongs to the form genus Phomopsis. In morphological structures the podblight fungus is identical with similar structures of the genus Phomopsis as laid down in Diedicke's (I3) revision of the group- 
that is, chambering of the pycnidia, formation of sclerotial stroma, presence of pycnospores and stylospores, and structure of the pycnidial wall. No stroma is formed by this fungus on the leaves. If this fact should be disregarded and Saccardo's classification followed, it should be classed as a Dothiorella or a Fusicoccum. Stylospores have been found to be abundant in most of the material collected and studied, but none were found in the herbarium material collected and identified by Ellis as Phoma subcircinata. However, isolations have been made from material which did not bear stylospores but developed them in cultures later, which shows that, although not always present, the fungus may produce them. On the other hand, the organism isolated from specimens bearing stylospores do not always produce them in culture. This fungus is very similar to a large group of other organisms which have long been classed as Phoma. In a taxonomic study of the group Diedicke (I3) transferred a number of species of Phoma to the genus Phomopsis. The podblight fungus does not differ essentially morphologically from the conidial stage of Diaporthe batatatis (E. and H.) Harter and Field, which was first described as Phoma batatae but found later by Harter and Field (2I) to be a species of Plomopsis. It is similar also to the organism causing fruitrot, leafspot, and stemblight of eggplant, which was known as Phoma solani on the stem and fruit and as Phyllosticta hortorum on the leaves, both of which were found by Harter (20) to be caused by the same organism and to belong to the form genus Phomopsis.

Some years before Phoma subcircinata was described by Ellis and Everhart, Cooke and Ellis (9, p. 93) described Sphaeria (Diaporthe) phaseolarum occurring on bean stalks as follows:

Gregaria, tecta. Peritheciis globosis, immersis, minimis. Ostiolis spinaeformibus, atris, erumpentibus, Ascis clavatis. Sporidiis lanceolatis, quadrinucleatis. Sporidia $0.016 \mathrm{~mm}$.

In the original description no type location was given; neither is it apparent in this or subsequent descriptions whether the fungus was found on Lima beans or other varieties. In the absence of these facts, together with the imperfect description, it would be difficult to identify correctly the fungus if it had not been more fully described later by Ellis and Everhart (14, p. 460) as follows:

Diaporthe phaseolorum (C. \& E.).

Sphaeria phaseolorum, C. \& E. Grev. VI, p. 93.

Diaporthe phaseolorum, Sacc. Syll. 2635, Cke. Syn. 2423.

Exsicc. E11. N. A. F. I88.

Perithecia gregarious, buried, very small. Ostiola spine-like, slender, projecting for $1 / 4-1 / 2 \mathrm{~mm}$. Asci clavate, $30-35$ by $6-7 \mu$. Sporidia biseriate, oblong-lanceolate, 4-nucleate, scarcely or only slightly constricted, Io-12 by $3 \mu$ (I6 $\mu$ long, Cke.).

On decaying bean vines left exposed through the winter, Newfield, N. J. Mostly around the nodes of the stem, the surface mostly blackened and the stroma limited within by a black line. 
The writer collected a quantity of Lima beans (pods and stems) at Vineland, N. J., in October, I9I4, and January, I9I5, which bore an abundance of pycnidia of the podblight fungus, generally known as Phoma subcircinata E. and E. After isolating the causal fungus the material was wintered out at Washington, D. C., and covered with leaves and dirt. On June 2 perithecia of the genus Diaporthe were found to be abundant on stems and pods of this material. The perithecia were scattered and buried in the tissue of the host except the beaks which were long and projecting and somewhat bent as shown by Plate 43, D. A pycnidial fungus was isolated from single ascospores which was identical with the one isolated from the material before it was wintered out Subcultures of this strain were used in inoculation experiments and produced infections identical with that produced by subcultures from isolations of single pycnospores. This strain (known as 598), as well as others isolated directly from pycnospores, produced stylospores. The perithecial stage has never developed in culture.

The perithecia produced on the wintered-out material varied in size from I 58.0 to $355.5 \mu$, average $25 \mathrm{I} .9 \mu$; the asci 28.0 to $46.2 \mu$ by 5.2 to $8.0 \mu$, average 37.4 by $6.73 \mu$; the ascospores 6.4 to I $2.0 \mu$ by 2.3 to $4.0 \mu$, average 9.5 by $2.93 \mu$. The perithecia of type material varied in size from I 58.0 to $237.0 \mu$, average 2 I $5.6 \mu$; the asci 28.0 to $44.0 \mu$ by 4.8 to $8.0 \mu$, average 33.6 by $7.0 \mu$; the ascospores 8.0 to 12.0 by 2.4 to $4.0 \mu$, average 10.0 by $3.3 \mu$. From the fact that the ascospores, asci, and perithecia together with other morphological characters of the two organisms are practically identical, it is concluded that they are the same fungus and should be known as Diaporthe phaseolorum (C. and E.) Sacc.

\section{MORPHOL,OGY}

PYCNIDIAL, STAGE

From the point of infection the hyphæ grow in all directions, invading practically all classes of cells except the bast, a layer of which (fig. I, $\mathrm{A}, \mathrm{B}, d)$ is found just below the epidermis. Figure $\mathrm{I}, \mathrm{A}$ and $\mathrm{B}, c$, shows parenchyma cells traversed by the hyphæ. Soon after the death of the cells the pycnidia begin to form, and develop very rapidly thereafter. The hyphal growth increases in the cavities below the stomata or in the intercellular spaces. From here it passes up between the bast cells which are often somewhat separated beneath the stomata. As growth increases, gnarls of hyphæ accumulate under the stomata and between the epidermis and the bast cells (fig. $\mathrm{r}, \mathrm{A}, \mathrm{B}, b$ ). From this point the fungus spreads out just beneath the epidermis and develops a more or less circular plate, the base of which rests on the bast cells. Figure I, A, shows an early stage in the development of the pycnidial plate. As the fungus growth continues, the epidermis is gradually elevated (fig. I, B, a) as the 
result of the pressure below. Definite cell layers of the pycnidium are laid down about this time or a little earlier. The pycnidium completes its full development soon thereafter (P1. 43, B).

The inner layer of the pycnidium is composed of hyalin cells from which the conidiophores arise. A slight cavity is formed at the center concomitant with the release of pressure by the rupture of the epidermis. Inclosed in this cavity numerous conidiophores are developed, extending toward the center from which the spores are cut off. As the spores increase in quantity, the cavity enlarges by the pushing back of the cells lining the cavity and probably by further lifting of the upper part of the pycnidium. It has not been possible to determine definitely when the opening from the pycnidial cavity to the outside through the beak is formed, but it probably takes place only after the pressure within has been greatly increased by the continued production of spores. It is believed,

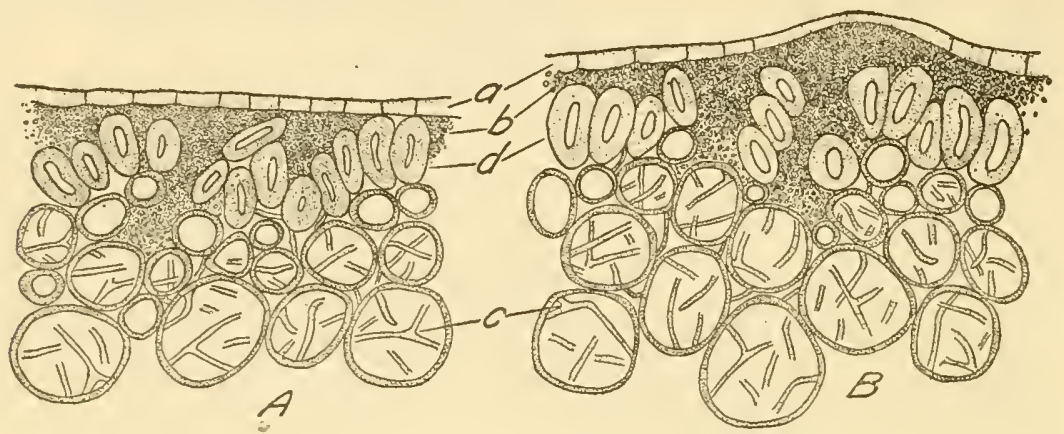

FIG. 1.-Diaporthe phaseolorum: $A$, An early stage in the formation of a pycnidium. The epidermis (a) is not yet disturbed but the hyphæ $(b)$ have accumulated directly beneath it. Note the coursing of the hyphæ through the parenchyma cells $(c) . \times_{13} ., B, A$ more advanced stage of figure $A$. Note the bulging of the epidermis $(a)$. $\times_{13}$.

however, that their expulsion is largely brought about through the absorption of water by the gelatinous mass in which the spores are embedded, a condition which has been found by Stewart (34) to occur for Guignardia aesculi (Pk.) Stewart.

The writer does not wish to leave the impression that the pycnidia develop only in the stomatal chambers, but that this is a common and natural place for their formation there can be no doubt. Even in young pycnidia it is not always easy, and sometimes is impossible, to tell whether or not they were being. developed just beneath a stoma. The bast cells of the pods of the Lima bean are very thick walled and are generally pressed so close together that it would be difficult, if not impossible, for the fungus to pass between them. These cells, however, are separated at certain places, and often just beneath a stoma, so it would be logical that they should form in such a cavity. From these facts it is evident that, in many cases at least, the pycnidium is developed beneath a stoma, and also at such other places where the bast cells are separated. 
The pycnidia vary greatly in size ( 158.0 to $475 \mu$, average $245.86 \mu$ from host). They are irregular in shape, chambered with an inner hyalin layer from which the conidiophores arise, and a dark outer layer much thickened and darkened above (Pl. 43, B, C), all characters typical - of the genus Phomopsis. Sometimes the contiguous sidewalls of two or more pycnidia are ruptured, forming a single cavity (Pl. 43, E). On the other hand, they may be pressed together but separated by a single dark wall and their respective hyalin inner layers, thereby forming a chain of pycnidia (P1. 43, C). The pycnidia can hardly be said to be embedded in a true stroma.

The pycnidia on the leaves and stems are lenticular in shape, rarely, or not at all chambered (P1. 43, A), fewer in number, and smaller than on the pods and usually isolated. They vary in size from $\mathrm{I} 97.5$ to $260.0 \mu$, average $219.0 \mu$.

The pycnospores are borne on slender, hyalin, simple conidiophores (fig. 2, a), $1 / 2$ to 3 times the length of the pycnospore. They are mostly oblong to fusoid

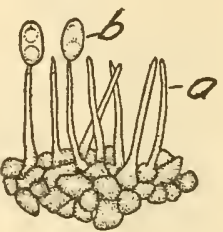

FiG. 2.-Diaporthe phaseolorum: L,ong, slender, fragile sporophores with two pycnospores attached. (a) Sporophores; (b) pycnospores. $\times_{500}$

(fig. $2, \mathrm{~b} ; 3$ ), hyalin, I-celled, usually straight, seldom slightly curved, with two large oil droplets. These droplets, sometimes pressed together in the center of the spore, give the appearance of a septum, a characteristic common to the genus Phomopsis and so deceptive that at a casual glance one might believe that a true septum was laid down. That the spore is but I-celled can readily be demonstrated by clearing

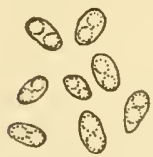

FIG. 3.-Diapor-

the phascolo-

rum: A group of pycnospores.

Note the oil droplets and variations in size and shape. $\times 500$.

it with a little salicylic acid. The variation in the size of the pycnospores from various sources is seen from the following measurements:

From host. -6.0 to 8.6 by 2.4 to 4 . I $\mu$, average 7.5 by $3.23 \mu$.

Stems of Melilotus alba. -5.6 to io.o by 2.4 to $4.0 \mu$, average 7.82 by 3. I $1 \mu$.

Corn meal. -5.4 to 8.2 by 2.4 to $3.4 \mu$, average 6.49 by $2.79 \mu$.

Irish potato cylinders. -5.4 to 8.5 by I. 7 to $3.0 \mu$, average 6.36 by $2.59 \mu$.

Corn-meal agar. -5.1 to 8.3 by 2.4 to $3.4 \mu$, average 6.78 by $2.85 \mu$.

Rice. -5.4 to 8.5 by 2.0 to $3.4 \mu$, average 6.45 by $2.80 \mu$.

It will be noted that the spores are relatively large in artificial cultures on stems of Melilotus alba, and small on cooked Irish potato cylinders. This difference has been found rather constant, and is probably associated with vigor of growth. Of all media tried stems of $M$. alba were found exceedingly favorable for spore formation, while cooked Irish potato cylinders were rather unfavorable. 
Under favorable conditions, such as in a nutrient broth or beef agar, the pycnospores germinate in about six to eight hours at room temper-

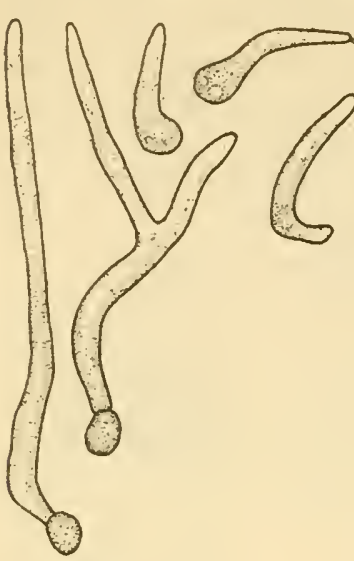

Frg. 4.-Diaporthe phaseolorum: Germinating pycnospores. $X_{500}$ ature. Previous to germination the spores become almost spherical and slightly enlarged. Usually but one germ tube develops, but occasionally two (fig. 4). One or both of the oil globules may disappear at this stage or remain until the germ tube is several times the length of the spore. Growth is rather slow at first, the hyphal growth attaining a length compared witn the diameter of the spores as shown in figure 4 in 48 hours. During this time branching may occur, and septa rarely are formed till later.

The bodies called stylospores are frequently found either alone or accompanying the pycnospores in pycnidia on the pods. They have never been found on the leaves. They are long, slender, hyalin, nonseptate, straight or curved bodies (fig. 5) borne on short, rather stout awlshaped simple hyalin stylosporophores (fig. 6). Figure 5 shows some stylosporophores with stylospores attached. They are produced but sparingly the early part of the season or when the pycnospores are most abundant. As the season advances the stylospores increase in number and appear to be associated, though not always, with a saprophytic existence. Following the death of the host and the gradual disappearance of the pycnospores the stylospores increase and finally become very

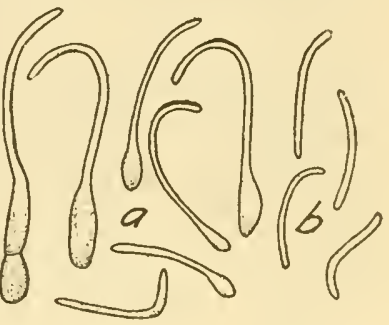

Fig. 5.-Diaporthe phaseolorum: Stylosporophores. (a) The stylosporophore is attached to the stylospore. (b) Stylospore not attached to the stylosporophore. $X_{500}$.

numerous. Specimens which bore practically no stylospores in the fall

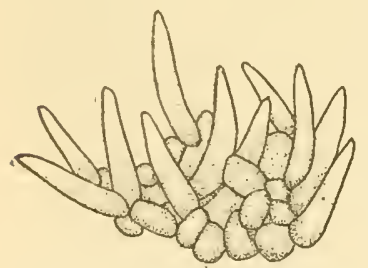

Fig. 6.-Diaporthe phaseolorum: A group of stylosporophores. $X_{500}$. bore them in increasing numbers throughout the winter. There is a possibility from the data at hand that the stylospores may be associated with a lack of food supply. They are produced in some culture media freely, but not until after the food supply becomes more or less exhausted. Although in cultures the pycnospores are usually exuded from the beak in seven days, the stylospores have never appeared sooner than II and generally not before I 5 to 30 days after inoculation. The average size of the winter crop of stylospores developed 
under natural conditions is considerably larger than those produced in the fall or in culture. Measurements made of the fall stylospores from the host vary from II.7 to 3 I.O $\mu$ by $\mathrm{I} .4$ to $2.0 \mu$, average 22.83 by $1.73 \mu$, while those collected on February 7 varied from 20.6 to $54.4 \mu$ by 1.38 to $2.4 \mu$, average 32.44 by $2.0 \mu$. They are produced in culture on rice, corn meal, Irish potato cylinders, and stems of Melilotus alba and vary in length from I I.7 to $54.4 \mu$ and in width from 1.38 to $2.4 \mu$.

The function of these bodies is not known. Repeated attempts have been made to germinate them but without success. Reddick (29) has suggested the possibility that they were paraphyses and Saccardo (3I, p. 264) regards them as conidiophores. Von Höhnel $(23, p .526)$, described a new genus, Myxolibertiella, to include those species having stylospores and pycnospores. He first placed the genus in the order Melanconiales but later in the order Phomatales. Bubák (2) and Diedicke (13) both regard them as spores. The latter investigator for convenience Fig. 7.-Diaporlhe phaseolorum: Mature hypha. Note the designated the Phoma-like

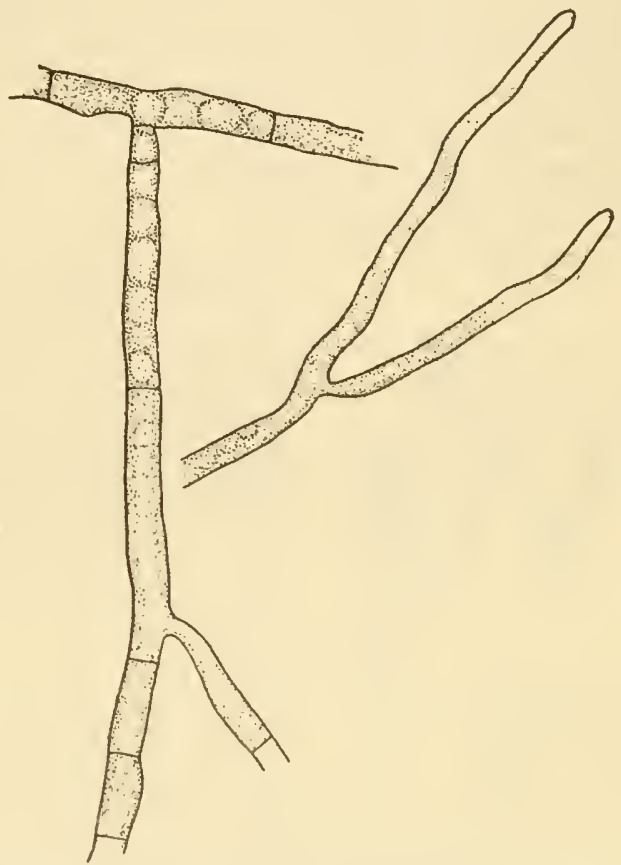

spores by the Greek letter alpha $(\alpha)$ and the stylospores by beta $(\beta)$. Shear (32), like Bubák, Diedicke, and others, regards these bodies as spores and designates them as scolecospores.

There is nothing peculiarly distinctive about the mycelium. It is hyalin, frequently branched, and septate. It varies considerably in width and is often supplied with enlargements which bear a slight resemblance to chlamydospores. When young the cells are supplied with small protoplasmic granules. When the hyphæ are old, the cells are filled more or less with oil globules or droplets (fig. 7).

\section{ASCOGENOUS STAGE}

Specimens of Lima beans consisting of stems and pods collected in October, 1914, and January I, 1915, at Vineland, N. J., were wintered out at Washington, D. C., and covered over with dirt and leaves. These 
specimens were kept under observation through the remainder of the winter and spring months. Pycnidia and pycnospores were found from time to time, as well as an increasing number of stylospores. On June 2 pods brought into the laboratory bore a considerable number of mature perithecia of an ascomycete, which was identified as Diaporthe phaseolorum (C. and E.) Sacc. The writer was away for five weeks previous to June 2 so it is not certain just when the development of perithecia began, and for that reason it was not possible to follow the complete course of development. The perithecia are scattered and buried beneath the surface, most of the beak protruding. Plate $43, \mathrm{D}$ and $\mathrm{F}$, shows diagrammatically the arrangement of the perithecia and relatively the depth they are sunken below the surface. Whether or not the perithecia are all formed in the cavities of old pycnidia has not been definitely de-

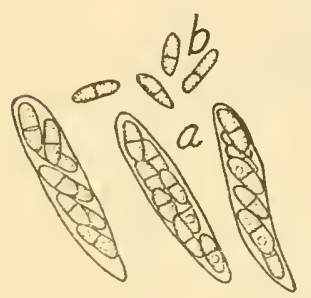

FIG. 8.--Diaporthe phaseolorum: (a) Asci and (b) ascospores. $X_{500}$ termined. The pycnidia are rather numerous and often coalesce, and as a matter of chance a perithecium might preempt a pycnidium and be formed therein. It is believed, however, that this is not the rule. The perithecia are not irregular in shape, as might be expected if they were formed in old pycnidia; but they usually bear a rather definite and constant form (P1. 43, F). They also have separate and distinct walls which differ from the layers of the pycnidium. In no case have the spores or stylospores ever been found associated with a perithecium, although these bodies were present on the host at the time.

The perithecia are slightly flattened, I 58 to $355.5 \mu$, average 25 I.9 $\mu$ in width and from i 10.6 to $205.4 \mu$, average $166.5 \mu$ in depth. The beaks, many times longer than wide, are usually curved or hooked (P1. 43, D), rarely straight, tapering gradually to the end. The perithecium, circumscribed by a dark layer of cells, is lined within by a thin, hyalin layer from which the asci arise. The perithecium is evidently almost or completely matured before the beak is formed. Plate 43, D, shows beaks just appearing through the epidermis. Sections through perithecia with beaks in the incipient stage show the wall layers to be perfectly formed and many mature asci present. The asci (fig. 8, a) are sessile, clavate or fusoid, 28.0 to $46.2 \mu$ by 5.2 to $8.0 \mu$, numerous, and contain eight spores arranged mostly biserially. The ascospores are apparently bound together or embedded in a gelatinous mass, since thcy are firmly held together even after the apparent disappearance of the ascus wall. The ascospores, (fig. $8, b$ ) measuring 6.4 to 12.0 by 2.3 to $4.0 \mu$, are spindle-shaped, oblong-lanceolate, $\mathrm{I}$-septate at or near the center, slightly or not at all constricted, and contain two to four oil dropiets. 
The ascospores germinate readily in most any nutrient medium in about six to eight hours by the development of a single germ tube from one or both cells (fig. 9). The hyphæ branch is 12 to 24 hours, and septa are laid down at about the same time. Growth is very rapid. At ordinary room temperature a colony from a single spore becomes visible to the naked eye in about five days. The ascogenous stage has not been produced in culture. The transfer of a colony from a single ascospore resulted after 7 to ro days in the production of the pycnidial stage on the same culture media on which pycnidia were developed by a transfer of pycnospores in the same length of time. In other words, there is no difference between the growth of the ascogenous strains and pycnidial strains on the same culture media.

\section{INOCULATION EXPERIMENTS}

The inoculation experiments on which the conclusions of the parasitism of the organism have been drawn were made in the greenhouse. It was found that Lima beans grow normally and produce fruit as well under greenhouse conditions as in the open field. Opportunities were therefore afforded to study the parasitism of this disease under controllable conditions and at any time of the year most suited to the needs of the work.

Controls were held with each experiment, the number and results of which are shown in Table I following a discussion of the inoculation experiments. The pods unless otherwise stated were inoculated by inserting spores and hyphæ into a wound made by a sterile needle. While

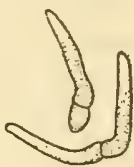

Fig. 9.-Diaporthe phascolorum: Germinating aseospores, $X_{500}$. later evidence will show that under suitable conditions infection may take place without wounding, the relative humidity of a greenhouse is usually so low that spores smeared on the surface often fail to germinate. It was necessary, therefore, to protect the spores from drying out by inserting them under the epidermis or by other means. In most cases it was impossible to protect the spores against drying, owing to the fact that when a Lima bean plant is frtiting abundantly it is generally too large to confine in an infection cage, though this was done with some smaller plants (see p. 486).

All inoculations were made from cultures grown on stems of Melilotus alba. The age of the culture was not considered or found important further than that the culture should be vigorous and fruiting abundantly. Spores were exuded from the pycnidium in about seven days after the culture was inoculated and continued to do so for 30 to 40 days thereafter or until the culture was dried. Spores were well suited for inoculation purposes until the culture medium was dried out.

Inoculations were made with six different strains. By a strain is here meant a difference in the source and not a difference in morphology or 
parasitology, since all were found to be identical organisms. For the sake of convenience in presentation each of the strains was given a separate number as follows: Strain 286 was isolated on October 26, 1914, from a Lima bean pod collected from a small patch at Vineland, N. J. Stylospores and pycnospores were abundant. Strain 420 was isolated from a Lima bean pod collected during the fall of 1914 by Mr. M. B. Waite in Maryland. Stylospores, as well as pycnospores, were present in abundance. Strain 447 was isolated from material collected on January 1 , 1915 , from the same field as No. 286. Strain 567 is a reisolation made on April I 2, 19I 5, from a pod that had been inoculated in the greenhouse on March I3, I9I5, with strain 447. Pycnospores were abundant, but there were no stylospores. Strain 598, as previously stated, resulted from the isolation on June 4, I9 5 , of a single ascospore from a pod that had been wintered out at Washington, D. C. Strain 601 was isolated on August 7, 1915, from leaves of Lima beans collected at Cape May, N. J., on August 5, I9I 5.

Other isolations of the same organism not used for inoculation purposes have also been made for the purpose of identification and comparison. Frequent reisolations were made from inoculated pods, one strain $(567)$ of which was used to make inoculations. From specimens inoculated with this strain the causal fungus was again recovered, thus fulfilling the requirement of Koch's postulates, claimed necessary to prove parasitism.

The first infection experiments were made on January I $_{5}, 1_{91}$, when 20 nearly mature pods on six small plants were inoculated, Io with organism 286 and 1o with organism 420 . After the pods were inoculated by inserting spores and hyphæ, the plants were sprayed with spores suspended in water. They were then kept in a paper-covered infection cage for 24 hours. On February 20, pycnidia were abundant on the stems and on six pods inoculated with No. 286. Of those inoculated with No. 420 , five pods were dead, and pycnidia were already on four and developed on one more after ro days in a moist chamber. In this case there were no leaf infections, though the stems, particularly the lower parts, were covered with pycnidia, the pycnidia developing most abundantly on the moribund stems and pods.

On March I3, 2I small plants were sprayed with organism 447. There were only three small, immature pods in all and they were inoculated by inserting spores and hyphæ. These plants were inclosed for 48 hours in paper-covered infection cages. Twelve days later the three pods were drying up, and pycnidia were present on one and developed on the two others after 7 days in a moist chamber. Here again no leaves were infected, and the pods did not show typical infections. These results were disappointing at the time, but it was discovered later that young leaves and pods were difficult to infect, mature parts being much more susceptible to the disease. 
On April 9, r9r5, twelve almost mature pods were inoculated by inserting spores and hyphæ in the usual way with organism 447 . The plants were too large to place in the infection cage. Seven days later the tissue for half an inch or so around the point of infection was visibly darker. Three days later some of the pods were withering, and pycnidia began breaking through the epidermis $1 / 2$ to $3 / 4$ inch from the point of inoculation. As long as the pods remain firm, the pycnidia form in more or less concentric rings; but concomitant with the withering of the pods the fungus rapidly invades all the tissue, and pycnidia break through the epidermis indiscriminately in a manner shown by Plate 42, C. Eight of these pods finally became infected.

April 20, nine half-grown pods were sprayed with a suspension of organism 447 in sterile water and kept in an infection cage for 24 hours. These specimens were kept under observation until June 2, but no infection had taken place. It is believed that the failure here is again due to the relative immaturity of the pods. These results agree with those of Pool and McKay (27), who were able to infect only mature leaves of sugar beets with Phoma betae (Oud.) Fr. Apparently the writer has succeeded in infecting young pods by wounding, but there is reason for doubt, owing to the fact that a small wound frequently results in serious injury and death of the pod, in which case the fungus quickly invades it as a saprophyte. On April 23, spores of organism 447 were inserted in five pods, and by June 2 pycnidia and spores were abundant on three and a few days later on one more, one remaining sound.

On June 2, pods bearing perithecia which contained mature asci were brought into the laboratory and thoroughly washed and disinfected in mercuric chlorid. The perithecia were carefully picked out and macerated in sterile water in a watch glass. Twenty-one nearly full-grown pods were inoculated by inserting ascospores and bits of broken tissue into wounds. Twelve days later thirteen pods showed unmistakable evidence of the disease, and by June 2 I all but four of the pods were well covered with the fruiting bodies. The writer does not claim any proof of the connection of the conidial and perfect stage from this experiment. It is included here because it forms a link in the chain of experiments performed with this organism. The results are justly open to the criticism that spores and hyphæ of the imperfect stage may have beei inserted, and it is not unlikely that such was the case.

On June 3, r9r5, fifteen pods were inoculated in the usual way with organism 567. By June I4, pycnidia were abundantly produced over an area an inch or more in diameter on ten pods, and on four others by June $2 \mathrm{I}$. One pod alone remained sound.

On June I4, seventeen pods were inoculated with organism 598 (ascospore strain). In four days the tissue around the wound on some pods began to darken, showing unmistakable and characteristic symptoms of the disease. As the pods were killed by the fungus, they were gathered 
and all but one bore numerous pycnidia by August 9. Cultures from some of these infected pods produced a growth characteristic of the pycnidial stage. On the same date spores of organism 598 were smeared on the surface of five nearly full-grown pods. There were no signs of infection on June $2 \mathrm{I}$, but by July 7 three showed evidence of infection, two remained sound. Seven pods of various ages were sprayed with organism 598 and confined in an infection cage for 30 hours. Pycnidia appeared on one of these pods on June $2 \mathrm{I}$ and on two others on August 9 as well as on the stems and some of the dead branches. The writer was away for sometime previous to August 2, and it is not definitely known just how the disease developed. It is probable, in view of the fact that the pods were dead and studded all over with pycnidia, that they succumbed sometime earlier.

On June 2 I twenty-one pods were inoculated with organism 598 in the usual way. One diseased pod was removed on June 29 , eighteen on July 7, and one on August i7. One of the inoculated pods could not be found, and was therefore regarded as not infected. There were ten checks held for this experiment, one of which became infected and the only one of all the checks (66) held at various times.

On August 17, ten pods were inoculated with organism 6or, and by September 3 six were well covered with pycnidia. Four remained sound. Of 19 pods inoculated with 601 on September 7 , ten showed typical infection on September 25. Nine remained sound.

A summary of the results is given in Table $I$.

TABLE I.-Summary of inoculation experiments of Lima beans

\begin{tabular}{|c|c|c|c|c|c|c|}
\hline Organism No. & $\begin{array}{l}\text { Date of in- } \\
\text { oculation. }\end{array}$ & How inoculated. & $\begin{array}{l}\text { Number in- } \\
\text { oculated. }\end{array}$ & $\begin{array}{l}\text { Num- } \\
\text { ber in- } \\
\text { fected. }\end{array}$ & $\begin{array}{l}\text { Num- } \\
\text { ber of } \\
\text { checks. }\end{array}$ & $\begin{array}{l}\text { Num- } \\
\text { ber of } \\
\text { checks } \\
\text { in- } \\
\text { fected. }\end{array}$ \\
\hline $286 \ldots \ldots \ldots . . .$. & $\begin{array}{l}\text { I9x } 5 . \\
\text { Jan. }{ }^{2} 5\end{array}$ & $\begin{array}{l}\text { By insertion of } \\
\text { spores in a wound. }\end{array}$ & Io pods... . & 6 & 5 & $\circ$ \\
\hline $420 \ldots \ldots$ & .. do.... & ....do............. & ...do... & 5 & 5 & 0 \\
\hline $447 \ldots \ldots$ & Mar. 13 & $\begin{array}{l}\text { Sprayed............ } \\
\text { Wounding........ }\end{array}$ & $\begin{array}{l}2 \text { I plants. . } \\
3 \text { pods.... }\end{array}$ & 0 & 6 & 0 \\
\hline $447 \cdots$ & Apr. & By wounding...... & I2 pods... & 8 & 5 & $\circ$ \\
\hline $447 \ldots \ldots \ldots \ldots$ & Apr. 20 & Spraying........... & 9 pods.... & 0 & 5 & 0 \\
\hline $447 \ldots \ldots \ldots \ldots \cdots$ & Apr. 23 & By wounding. . . . . & 5 pods..... & 4 & 5 & 0 \\
\hline $\begin{array}{l}\text { Fragments of peri- } \\
\text { thecia contain- } \\
\text { ing asci from } \\
\text { pods. }\end{array}$ & June & ....do............ & 2 I pods.... & I7 & 8 & c \\
\hline $5^{6} 7 \ldots \ldots \ldots \ldots \ldots$ & June 3 & .....do. & I 5 pods.... & I4 & 6 & c \\
\hline $598 \ldots \ldots \ldots \ldots \ldots$ & June 14 & ....do. ........... & I 7 pods. . . & x6 & 6 & $\circ$ \\
\hline $590 \ldots$ & ...do.... & $\begin{array}{l}\text { spores smeared on } \\
\text { pods. }\end{array}$ & 5 pods. & 3 & & \\
\hline $598 \ldots \ldots \ldots \ldots$ & ..do..... & Sprayed. & 7 pods.... & 3 & & \\
\hline $\begin{array}{l}598 . \\
601 .\end{array}$ & June 2 I & By wounding. & 2 I pods... & 20 & IO & I \\
\hline $601 . . . \ldots \ldots$ & $\begin{array}{l}\text { Aug. } \quad \text { I } 7 \\
\text { Sept. } 7\end{array}$ & ..... do....... & Iopod & 6 & & \\
\hline & & & 19 & & $J$ & \\
\hline
\end{tabular}




\section{PERPETUATION OF THE FUNGUS}

The finding of mature asci of this fungus on June 2, I915, and on June II, I9I 6 , and later on the dead vines and pods wintered out at Washington, D. C., and on similar material under field conditions at Vineland, N. J., at about the same season of the year shows one way the fungus may live through the winter. This method of perpetuation is, however, not the only one. At intervals from October until June pycnospores were frequently found, and the fungus was isolated at will from field material. It is interesting to note in this connection that the pycnospores were produced periodically during the winter season, depending upon weather conditions. Following a period of a few days of relatively warm, rainy weather, they could nearly always be found in more or less abundance. For example, pycnospores were found on material examined on October 24, January 2, I4, and 2I, February 7, March 6, April I4, and June 2. Isolations were made on October 24, January 2, February 7, May 3I, and June 2. Similar results were obtained with Phomopsis vexans (Sacc. and Syd.) Harter, the pycnospores of which were found in May and June on wintered-out material. However, the same material examined in December, January, February, and April bore no pycnospores but the stylospores appeared to be more numerous during the spring months. The appearance of pycnospores was roughly coordinated with rainfall and temperature, since on May 22, following a period of rainy weather and relatively high temperatures, they were found in great abundance.

It is likely also that the organism may live for a considerable time in the seed. The writer has isolated it in pure culture from the interior of both seeds and pods after surface disinfection in mercuric chlorid. From these results it is apparent that the fungus invades all parts and it is not unlikely that it is carried fron one season to the next on the seed. That the fungus is not readily killed by drying is evident from the fact that it was isolated from dried specimens kept in the laboratory for nine months. It would probably survive such conditions even longer. These results are supported by the earlier work of Halstead $(I 7)$, who in Igor called attention to the fact that the seeds were invaded by the fungus and suggested the possibility that it was carried through the season by that means.

\section{MODE OF INFECTION}

It is not always easy to explain how a parasite gains entrance into its host. It is safe to conclude that, if a fungus is parasitic, it may enter through wounds, it being merely necessary to show that the host is subject to wounding under natural conditions. Other types of penetration as, for example, through the unbroken epidermis or by way of the stomata are not always easy to demonstrate. There is no doubt that physical factors such as rainfall, temperature, humidity, and stomatal movement all play an important rôle in the penetration of the epidermis 
or stomata by certain parasites. In this connection it is interesting to note the results of Pool and McKay (28), who have studied in some detail the relation of stomatal movement to infection with Cercospora beticola Sacc. These investigators showed that the germ tubes entered only when the stomata were open, the movement of which was closely associated with a relatively high humidity, warm temperature, and light. Their results further showed that mature leaves were more readily infected and possessed a pore opening almost twice as large as young immature ones. The writer obtained similar results with the Lima bean fungus. It was found, as already pointed out, that young immature pods were not infected without wounding while mature pods could easily be. This difference may be due at least in part to the difference in the size of the stomatal aperture but more likely to the fact that immature stomata do not open, thus preventing the entrance of the hyphæ. Under humid conditions the spores germinate and produce a germ tube
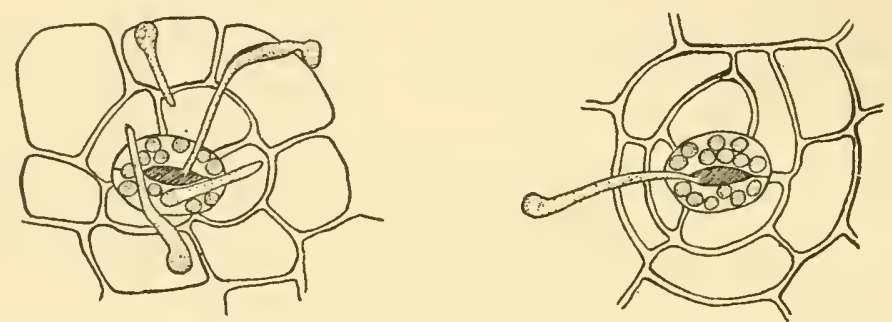

Fig. 10.-Diaporthe phaseolorum: Some of the germ tubes of the pycnospores penetrating the stomata two days after the pods were sprayed, and other germinated spores lying alongside the stomata and growing toward or away from the aperture. $\times_{260}$.

20 or 30 times the length of the spore in 24 to 48 hours. This is rather a feeble growth but the spores do not germinate readily in water, and then only a small percentage at that. On pods that had been sprayed with a spore suspension in water the germ tubes were found penetrating the stomata as shown by figure Io.

It is evidently a matter of chance when a germ tube finds its way into a stoma, since, if there was any attractive force, the germ tubes might be expected to head that way, which is apparently not the case. The germ tubes, as often observed by the writer and illustrated by figure ro, grow just as frequently alongside or away from the stomata as toward them, showing that there is no appreciable chemotactic influence. Entrance of the stoma would be easy so far as relative size of germ tube and stomatal aperature are concerned. In fact, it would not be impossible and it may actually happen that the spores fall directly through the pore into the intercellular space beneath. Measurements of the pores showed them to vary in length from 22 to $28 \mu$ and in width from 5 to $7 \mu$ when open, the germ tube of the spore in width from 2 to $3.5 \mu$, and the spore itself from 6 to $8.6 \mu$ by 2.4 to 4 .I $\mu$. Considering the relative size of 
the stomatal pore and the spore of the fungus, it is quite reasonable to conceive of an infection even during dry times, an event which actually does sometimes take place. It must of course be admitted, and the observed fact supports such a conclusion, that the number of infections by a fungus of this type during dry weather is relatively small compared with those during a period of rainfall or damp weather. Jones, Giddings, and Lutman (25) pointed out that moist, damp weather was conducive to the germination of the spores of Phytophthora infestans and made the interesting observation that the germ tube penetrated the leaf of an Irish potato through the epidermis as well as through the stomata. Similar observations were made by Jones (24), who found that the germ tube of Macrosporium solani E. and M. may penetrate the epidermis, as well as the stomata of Irish potatoes. The writer found no instance of penetration of Lima bean pods except through the stomata, and Pool and McKay (28) make a similar statement for Cercospora beticola.

The inoculation experiments already described have shown that infection takes place readily through wounds, perhaps made chiefly by wind, and by means of pickers. In ordinary farm practice the pole Lima bean is usually trained up several feet above the ground. Exposed thus to the wind, the vines are whipped around and the pods wounded by rubbing against the stems, poles, or wires on which they are trained. A careful examination will readily show the bruised spots on pods exposed to such conditions. Pickers also, in searching through the foliage, may likewise brush or press the immature pods against stems or poles, bruising them in a similar manner. The reddish, streaked appearance in localized spots often observed on bean pods is characteristic of wounds made by constant brushing or rubbing of the pod against a hard surface. It is in such areas that infections are frequently found.

The relation of insects to infection has not been studied.

\section{DISSEMINATION}

The dissemination of the podblight of Lima beans must be considered from two standpoints: (I) Over short distances, and (2) over long distances, as from one district or State to another. As to the first of these, there are several ways in which the spores may be carried from plant to plant or from one field to another. It is not unlikely that insects, whether they feed on the pods or not, play an important part in the distribution of the spores. During wet periods the spores are exuded from the pycnidium, and any insect frequenting the diseased pods is likely to carry the spores about on its body. Pickers, too, in searching through the foliage for mature fruit, are likely also to distribute the spores to unpicked pods, where, under favorable conditions, new infections will start. It is interesting to note in this connection that this and certain diseases of other crops seldom become serious until about picking time. There are two possible explanations for this. One is 
that the host may be more susceptible at this age; and the other that picking of the fruit, especially if the foliage is wet with dew or from rain, results in a liberal distribution of the spores.

That strong winds may be responsible for severe outbreaks of this and other diseases is evident from the fact that Cook $\left(6, p .5^{I} 7^{-5}{ }^{18}\right)$ found a serious outbreak in a certain section of New Jersey previously visited by a severe windstorm. It is, of course, natural to conclude, as Cook assumed and the writer has frequently observed, that injury to pods and foliage during such a storm would add to the chances of infection. It is believed that the part played by the wind in disseminating fungus spores has been very greatly underestimated. It is a well-known fact that the pollen of pine trees is carried long distances. Dr. Albert Mann, of the Bureau of Plant Industry, found ${ }^{1}$ a large variety of fungus spores collected on a gelatin plate exposed for about I 5 minutes at a distance of I mile above the surface of the earth. This readily shows that spores are freely air-borne over long distances, and this fact alone may account for the serious outbreak of a disease in isolated sections.

Owing to the fact that the causal organism can readily be isolated from the seed, it is likely that this affords the principal means of distributing it over long distances. Fruiting bodies have also been found on infected seed. This shows the great necessity of saving seed only from fields where this disease does not occur.

\section{CULTURAI, CHARACTERISTICS OF THE FUNGUS}

The fungus produces hyphæ on nearly all of the culture media in ordinary use. The pycnidia, on the other hand, are rarely produced on agars, but freely on media containing starch, such as rice or corn meal. A study of the growth and production of fruiting bodies was made on the following media: String-bean agar, Irish potato agar, beef agar, corn-meal agar, cooked rice, cooked corn meal, potato cylinders, and stems of Melilotus alba. These media were selected because they are in common use in the laboratory of Cotton, Truck, and Forage Crop disease investigations, and because some (corn meal and rice) were known to be particularly favorable for the growth of other very similar organisms, thus affording an opportunity for comparison. Other media might have served the same purpose.

The experiment was carried out by inoculating five tubes (I00 c. c. flasks, in case of corn meal) with spores from a Io-day-old culture on stems of Melilotus alba. After inoculation the tubes were kept in the light and exposed to the temperature of the laboratory room $\left(2 \mathrm{I}^{\circ}-25^{\circ} \mathrm{C}\right.$. $)$.

STRING-BEAN AGAR. - This on the whole has been a poor medium for this fungus. Growth of hyphæ started promptly and was visible in two days in slanted tubes of 
the medium. At the end of 9 days three dark bodies, which were at that time thought to be pycnidia, and which probably were sterile ones, were developed. These cultures were kept under observation for $7^{2}$ days, and no more pycnidia and no spores were found.

IRISH POTATO AGAR.-There was a visible vegetative growth in two days which continued to increase for about one week. A few scattered pycnidia appeared in all tubes but one. These were kept under observation for 72 days, and no spores or stylospores were ever produced.

BEEF AGAR.-A rapid vegetative growth during the first seven days of growth. Thereafter the hyphæ became fluffy and cottony. No pycnidia were formed in any of the tubes during the whole course of the experiment.

CORN-MEAL AGAR.- Growth was not visible in two days, but in four days the hyphæ had spread over an area $1 / 2$ inch in diameter. In six days dark specks appeared which later developed into mature pycnidia. At the end of $\mathrm{I}_{3}$ days the slimy white, creamy masses began to exude from the pycnidia. These cultures were frequently examined thereafter for stylospores, but none were found until after 34 days, when they appeared in great abundance. When stylospores and pycnospores are both produced, the former always appear after, and never before, the production of the latter.

COOKED RICE.-Rice has proved to be a good medium for the growth of this organism. Hyphæ were conspicuous and pycnidia began to form in 4 days. From that time the pycnidia increased in number and spores began to exude in 7 days. A heavy, black stromatic mass, in which the pycnidia were embedded, was formed. As the medium dried out, these stromatic masses were left as conspicuous domelike projections over the surface of the medium. The pycnospores were exuded in slimy, yellowish, viscid masses in such quantities as to flow over the top of the stroma and mostly to cover the surface of the medium. Stylospores were found sparingly in 22 days and abundantly in 34 days.

COOKED CORN MEAL.-Corn meal was found to be one of the best media for this and other closely related fungi, such as Phomopsis vexans, Plenodomus destruens, and Diaporthe batatatis. In 5 days the hyphæ covered most of the surface of the corn meal in roo-c. c. flasks, and pycnidia began to form. The pycnidia were produced in great numbers in a more or less well-developed stroma which bore characteristics similar to those on rice. The small slimy droplets containing pycnospores were first noticed at the end of ${ }_{3} 3$ days. The slimy exudate increased in amount until the droplets became quite large and flowed over the sides of the stroma, eventually covering nearly the whole surface of the medium. The stroma and pycnidia were dark on top and somewhat raised above the surface of the medium. As the corn meal dried out, the surface became more or less crusty and rugose. Stylospores were found for the first time at the end of 22 days.

PotATO CYLINDERS. - On this medium abundant mycelium was produced. A cottony, white growth covered one-third of the potato slant in two days and completely in four days. In five days incipient pycnidia were seen which later developed into a more or less stromatic mass. These masses were at first whitish on top, but later turned darker. In 22 days pycnospores were exuding slightly, and stylospores were present. At the end of 34 days the stylospores had become more abundant than on any other medium; the pycnospores, on the other hand, were relatively few.

STEMS OF MELILOTUS ALBA.-This medium, everything considered, is the best of any so far used. It gives a maximum amount of spores with a minimum of mycelium. There were no signs of growth in two days, but in five days numerous pycnidia began to form, and these soon became conspicuous as black specks studding the surface of the stems. The beaks were comparatively long and conspicuous. In one week under optimum conditions the viscid, creamy droplets in which the spores are em- 
bedded were noticeable on the end of the beak. These droplets gradually enlarged and finally overflowed the pycnidium, coalescing with similar droplets from other pycnidia and thereby forming an almost continuous liquid covering of the substratum. A stroma was not formed on stems of Melilotus alba. In this particular experiment no stylospores were formed. In other cultures, however, of the same organism on $M$. alba stems a few stylospores were found.

\section{EFFECT OF LIGHT ON GROWTH}

The literature is full of the records of experiments on the effect of light on growth and development of chlorophyll-bearing plants, as well as fungi. It would be useless to review all or any considerable part of these records here. It is evident, however, from a perusal of some of these publications that no general, sweeping conciusions can be drawn that will apply to all fungi alike. Recent results, on the other hand, show that under similar conditions individual fungi may be expected to respond differently. In support of this last statement, reference may be made to the results of Coons ( $I O$ ), who found that light was a determining factor in the production of pycnidia with Plenodomus fuscomaculans (Sacc.) Coons. The writer (I9), on the other hand, working with a different species of Plenodomus, $P$. destruens Harter, found that the absence of light did not inlibit the production of pycnidia. That the absence of light very greatly inhibited, but did not entirely prevent, the production of pycnidia by Diaporthe batatatis, was shown by Harter and Field (2I) in another experiment. The writer has obtained similar results, as yet unpublished, with other fungi.

The influence of light on growth and production of fruiting bodies of the pycnidial stage of Diaporthe phaseolorum was determined by inoculating stems of Melilotus alba in test tubes and exposing one-half of the set to light and excluding the light from the other tubes by wrapping with black paper, which was found by previous test to prohibit the passage of light. The tubes were all tightly plugged with cotton. The cotton plugs alone were left exposed, so as to permit aeration. The two series were then placed on a table in the center of the laboratory room and kept under observation for 25 days. The cultures began to dry up about that time and development was accordingly arrested. The tubes kept in the dark were examined for a few minutes every few days for the purpose of taking notes and were for that length of time exposed to the light. While this brief period can not be regarded as having no influence on the results, exposure to the light for such a short time would certainly have no marked effect. The growths of mycelium in the cultures in the light and those in the dark were about the same at the end of three days, but from that time the inycelial growth in the dark was relatively more abundant and more cottony. In tubes in the light, on the other hand, there was, as has always been, a minimum of mycelium on stems of Melilotus alba. At the end of six days pycnidia 
were forming in large numbers in all tubes in the light and in smaller numbers in all those in the dark. The ratio between the number of pycnidia formed in the light and in the dark remained nearly constant, the fruiting bodies forming in all tubes, but they were better developed in the light. In one week spores began to exude from the pycnidia both in the light and in the dark. From this time spores continued to be exuded, but here again the amount of the exudate was relatively less in the dark. Toward the close of the experiment, however, there appeared to be a relative increase in the exudate from the pycnidia formed in tubes in the dark. But one conclusion can be drawn from these results, that while the dark retards the production of fruiting bodies and accelerates vegetative growth, it is not as marked as the results obtained with other fungi by the writer and others.

\section{INFLUENCE OF TEMPERATURE ON GROWTH}

To determine the influence of temperature on growth I $_{2}$ (No. 2, 3, 5 , $6,8,9,10,15,17,18,19$, and 20) of the 20 chambers in an Altwann incubator were used. Tubes of cooked rice were inoculated with spores of the fungus and immediately placed in the chambers, where they were kept exposed to the respective temperatures for a period of 27 days, at the end of which time growth had practically stopped. No growth took

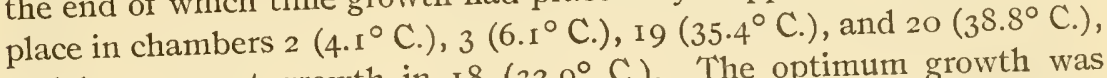
and but a scant growth in $18\left(32.9^{\circ} \mathrm{C}\right.$. $)$. The optimum growth was found in chambers $15\left(26.5^{\circ} \mathrm{C}\right.$.) and $17\left(30.5^{\circ} \mathrm{C}\right.$. $)$. The growth of hyphæ decreased relatively with the increase and decrease of the temperature from these limits of the optimum. In chambers $9\left(17.4^{\circ} \mathrm{C}\right.$.), IO ( $9.4^{\circ}$ C. ), I5 $\left(26.5^{\circ}\right.$ C. $)$, I7 $\left(30.5^{\circ}\right.$ C. $)$, and $18\left(32.9^{\circ}\right.$ C. $)$ stromatic masses of pseudoparenchymous tissue were produced which macroscopically looked like pycnidia. A careful examination of these bodies, however, showed that, while they bore some resemblance to pycnidia, no cavity had been produced within them and no pycnospores were found. The cause for this was later found to be due to a lack of sufficient aeration, resulting probably in a reduced oxygen supply. A subsequent experiment in which cultures of the organism on cooked rice were exposed in a chamber in which most of the oxygen had been removed by a mixture of pyrogallic acid and sodium hydroxid showed that while mycelial growth continued under such conditions the production of fruiting bodies was inhibited. In addition to the fact that the cultures in the Altmann chambers were kept in the dark, the absence of oxygen, which in itself was found, as already shown, to reduce somewhat the production of fruiting bodies, evidently accounted for the failure to produce pycnidia in the cited cases.

The growth of the podblight fungus in artificial cultures is schematically shown in figure I I. 


\section{INFLUENCE OF TOXIC AGENTS ON GERMINATION OF SPORES}

Perhaps no chemical substance has been more generally studied in its relation to the growth of plants than copper salts. This is perhaps due to its well-known efficiency as a fungicide, following the discovery of which a large amount of work was undertaken to determine the concentration of copper salts necessary to prevent germination or bring about the death of the spores of a great variety of fungi. Much of this work was done with saprophytes, and consequently has little more than a scientific interest, while the practical side of the problem was evident from the fact that the toxicity to germinating spores of many well-known parasites was established. Because of the various uses that chemical substances may be put to, such as antiseptics, disinfectants, etc., the toxic action of many

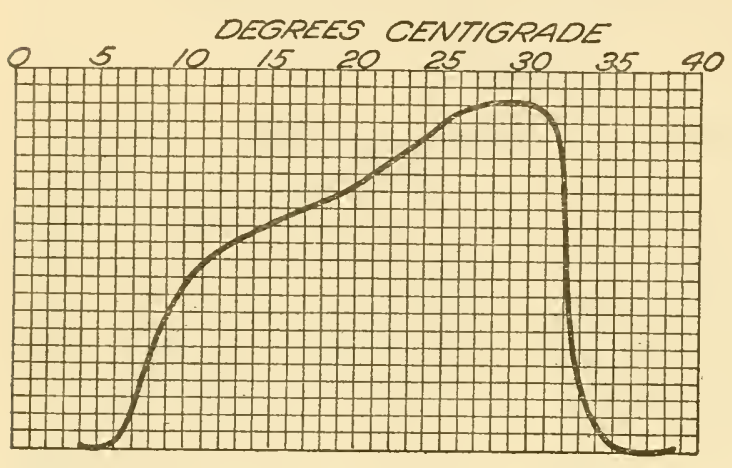

Fig. Ir.-Diaporthe phaseolorum: Graphic representation of growth on cooked rice at different temperatures. salts, metals, and acids, alone and in combination, on flowering plants and fungus spores have been extensively studied, and as a result an extensive literature on the subject has accumulated. As might be expected, the results have been very variable and often contradictory. In general, however, all investigations have shown that copper salts, among other chemical substances, are exceedingly toxic to all germinating spores and to the seedlings of flowering plants. Coupin $(I I)$ has shown by experiments that I part of copper sulphate to $700,000,000$ parts of water is sufficient to retard the root growth of wheat seedlings, and the writer has proved (I8) that a small amount of a single alkali salt, such as sodium chlorid, sodium carbonate, and magnesium sulphate in water cultures, inhibits the growth of the same plant. Heald (22) found $I / 5 I, 200$ and $I / 25,600$ gram-molecule per liter of copper sulphate to be toxic to Pisum sativum and Zea mays, respectively. According to Moore and Kellerman (26) I part of copper sulphate to 500,000 parts of water killed Closterium moniliferum in 4 days and I part of copper sulpliate to 3,000,000 parts of water killed Anabaena flos-aque in three days. Uroglena americana was even more sensitive and was killed in 16 hours in I part of copper sulphate to $10,000,000$ parts of water.

These few references show the extreme sensitiveness of some of the flowering plants and some algæ to copper salts, and at the same time the variability in their resistance. Although not strictly comparable with 
flowering plants, because of the different methods or experimentation and standards of measurement, the spores of fungi show equally great variability and sensibility to copper salts and other toxic substances. Clark (3) found that Penicillium glaucum was injured by copper sulphate at a concentration somewhere between $N / 2,048$ and $N / I, 024$, while Aspergillus flavus would endure a concentration of $N / 512$ to $N / 256$, two to four times as great. Crandall (I2), on the other hand, showed that the apple scab fungus is quite resistant to copper sulphate, the spores being only slightly retarded in germination in a solution of $\mathrm{I}$ to 100,000 , while a concentration of about I to 10,000 was necessary to entirely prevent germination. At this latter concentration some of the common molds, however, grew quite well. Temperature was found by Brooks (I) to influence the percentage of germination of the spores of certain fungi in the same concentration of a toxic substance. By an extensive series of experiments he found that Penicillium glaucum gave medium growth in $N / 128$ copper sulphate at $20^{\circ} \mathrm{C}$, Monilia fructigena did not germinate in $N / 16$ copper sulphate at $25^{\circ}$ to $30^{\circ} \mathrm{C}$., but at $15^{\circ} \mathrm{C}$. I 2 per cent, at $10^{\circ} \mathrm{C}$. 30 per cent, and at $5^{\circ} \mathrm{C}$. 49 per cent.

No attempt has been made to review all the extensive literature on the effect of toxic substances on plant growth. 'The results of the work of the different investigators are very conflicting, due, perhaps in part at least, to the different methods of experimentation employed and the different standards of measurement.

During the time the podblight fungus of Lima bean has been under investigation many interesting observations have been made trom time to time on the effect of certain chemical substances commonly used in the laboratory on the germination of the spores. The use of a solution of mercuric chlorid for disinfecting field specimens preparatory to isoiating the fungus led to a study of the strength of this solution necessary to kill the spores $n$ a given time. A similar study was made with formaldehyde because of its possible use in disinfecting infected seed, and with copper sulphate, a well-known constituent of Bordeaux mixture, sometime recommended as a spray in controlling the disease in the field.

\section{METHOD OF EXPERIMENTATION}

Preliminary experiments showed that the use of Van Tieghem cells to determine the toxic-limit for the germination of the spores was exceedingly unreliable and was consequently abandoned. Although this method has been generally used, it is likely that many of the conflicting results may be attributed to it. In fact, the writer found that each test in Van Tieghem cells might be expected to give different results, probably owing to the variation in vapor pressure or to some slight accident overlooked, unexpected, and unaccounted for. After considering the different methods that might be used, the writer concluded 
to employ the method frequently used in medical bacteriology to determine the germicidal value of certain chemicals. This takes more into account the actual death of the organism rather than the strength that inhibits growth. It seems that the same method should apply equaily well to fungi and is easier of determination and nore reliable, since the length of time the organism is exposed plays an important part also, and can be more accurately gauged. It is a well-known fact that a fungicide may merely inhibit growth when the spores are exposed to it for a certain length of time but may kill them on prolonged exposure. In these experiments the time the spores were exposed to the fungicide was relatively short, the concentration of the solution being proportionately strong to produce death in a comparatively short time. This method eliminated the necessity of taking into account, among other things, the temperature which Brooks ( $I$ ) found to play such an important part in germination of the spores of some fungi.

The pycnospores of Diaporthe phaseolorum were found to grow well in beef agar +15 on Fuller's scale; and therefore this medium was used in which to test germination. The spores from a culture on Melilotus alba were transferred by a small platinum loop to a solution of the fungicide of the desired concentration and mixed by a wide circularly swinging motion of the arm with the plugged end up, or by vigorous shaking. At the end of one minute, two minutes, and every two minutes thereafter up to the suspected limit of endurance, a loopful of the mixture was transferred to a tube of liquefied agar and, after mixing by shaking, a plate was poured. Control plates were made by transferring a loopful of spores from the same test culture to a sterile water tube and a loopful from this tube to a tube of liquefied agar. This method was followed with each of the fungicides and repeated as often as necessary to establish the toxic limit. The plates were kept at room temperature in the laboratory. The colonies in the control plates appeared in about two days. Notes were taken from time to time for seven days, after which they were thrown out, for, if growth took place at all, it would do so before that time.

\section{RESULTS OF EXPERIMENTS}

The results of these experiments are given in Table II.

The mercuric-chlorid and copper-sulphate solutions were made in advance and kept corked in the ice box until needed. Because of the instability of the formaldehyde, the solutions were prepared just before using and in such a way that the fractional parts given in Table II are based on a hypothetical formaldehyde solution of a strengtll of roo per cent. 
TABLE II.-The results of exposing pycnospores of Diaporthe phaseolorum to different strengths of mercuric chlorid, copper sulphate, and formaldehyde for different lengths of time

\begin{tabular}{|c|c|c|c|c|c|c|c|c|c|c|}
\hline \multirow{2}{*}{$\begin{array}{l}\text { Time of } \\
\text { exposure. }\end{array}$} & \multicolumn{3}{|c|}{ Copper sulphate. } & \multicolumn{3}{|c|}{ Formaldehyde. } & \multicolumn{4}{|c|}{ Mercuric chlorid. } \\
\hline & $N / 12.5$ & $\dot{N} / 31.25$ & $N / 62.5$ & I:100 & $I: 250$ & I:500 & $N / 135$ & $N / I, 350$ & $N / 2,700$ & $N / 4,050$ \\
\hline Minutes. & $a_{100}$ & 100 & 100 & 75 & 85 & 100 & 0 & 0 & 50 & 100 \\
\hline 2 & 35 & 65 & $\ldots \ldots$ & 0 & 30 & 100 & 0 & 0 & 0 & 100 \\
\hline 4 & 5 & 55 & 90 & $\ldots \ldots$ & 0 & 85 & $\ldots \ldots$ & $\ldots \ldots$ & $\ldots \ldots$ & 75 \\
\hline 6 & $\ldots \ldots$ & 25 & $\ldots \ldots$ & $\ldots \ldots$ & $\ldots \ldots \ldots$ & IO & $\ldots \ldots$ & $\ldots \ldots$ & $\ldots \ldots$ & 50 \\
\hline 8 & $\ldots \ldots$ & 15 & 75 & $\ldots \ldots$ & $\ldots \ldots$ & 0 & $\ldots \ldots$ & $\ldots \ldots$ & $\ldots \ldots$ & 0 \\
\hline IO & $\ldots \ldots$ & IO & $\ldots \ldots$ & $\ldots \ldots$ & $\ldots \ldots \ldots$ & $\ldots \ldots$ & $\ldots \ldots$ & $\ldots \ldots$ & $\ldots \ldots$ & $\ldots \ldots$ \\
\hline 12 & $\ldots \ldots$ & 5 & 45 & $\ldots \ldots$ & $\cdots \cdots$ & $\ldots \ldots$ & $\ldots \ldots$ & $\cdots \ldots$ & $\cdots \ldots$ & $\ldots \ldots$ \\
\hline 14 & $\ldots \ldots$ & 2 & $\cdots \cdots$ & $\ldots \ldots$ & $\cdots \ldots$ & $\cdots \cdots$ & $\ldots \ldots$ & $\cdots \cdots$ & $\cdots \cdots$ & $\cdots \cdots$ \\
\hline 16 & $\ldots \ldots \ldots$ & $\cdots \cdots$ & 20 & $\ldots \ldots$ & $\cdots \cdots$ & $\ldots \ldots$ & $\ldots \ldots$ & $\ldots \ldots$ & $\ldots \ldots$ & $\ldots \ldots$ \\
\hline I8 & $\ldots \ldots$ & $\ldots \ldots \ldots$ & $\ldots \ldots$ & $\ldots \ldots$ & $\ldots \ldots \ldots$ & $\ldots \ldots$ & $\ldots \ldots$ & $\ldots \ldots$ & $\cdots \cdots$ & $\ldots \ldots$ \\
\hline 20 & $\cdots \cdots$ & $\cdots \ldots$ & 2 & $\cdots \cdots$ & $\ldots \ldots \ldots$ & $\ldots \ldots$ & $\cdots \cdots$ & $\ldots \ldots$ & $\ldots \ldots$ & $\ldots \ldots$ \\
\hline
\end{tabular}

$a$ In this and corresponding columns are given the percentage of germination as estimated at the close of the experiment. Water controls were made in every case in which the germination was arbitrarily placed at roo per cent. These plates, together with those poured from a i minute exposure, served as controls for comparison in estimating percentages of germination.

Reference to the table will show that the spores were nearly all killed in four minutes in a $N / 12.5$ copper-sulphate solution, and in 14 minutes in a $N / 31.25$, and in 20 minutes in a $N / 62.5$ solution. It is interesting to compare these results with those of Clark (3), who found that the spores of several fungi exposed in a copper-sulphate solution were killed or injured as follows: A spergillus flavus (?) Link $\mathrm{N} / 4$ and greatly injured in $N / 256$, Sterigmatocystis niger Von Tieghem $N / 8$ and greatly injured in $N / I 28$, Oedocephalum albidum Sacc. $N / 64$ and greatly injured at $N / 256$, Botrytis vulgaris Fr. greatly injured at $N / I_{28}$, and Penicillium glaucum Link $N / I$ and greatly injured at $N / 256$. As will be seen, there is a wide difference between the strength of the solution necessary to kill and that required to injure greatly the spores. The writer found that none of the spores exposed for one minute to a solution of mercuric chlorid at a concentration of $N / x 35$ and $N / I, 350$ would germinate, and that only 50 per cent germinated when exposed for the same length of time in a concentration of $N / 3,700$. At the greater dilution, $N / 4,050,50$ per cent germinated after an exposure for six minutes. Clark (3) found that spores of A. flavns, S. niger, $P$. glaucum were killed in a $N / 4,096$ mercuric chlorid, O. albidum in a $N / x 6,384$, and $B$. vulgaris in a $N / 65,536$. The spores of these fungi were killed in the solutions of the toxic substance more dilute than that required to kill the pycnospores of Diaporthe phaseolorum, but they were likewise subjected to the solution for a longer time. In another work Clark (4) has shown that Rhizopus nigricans was killed in, 75 seconds in a solution of mercuric chlorid $\mathrm{I}$ to 3,700 .

Formaldehyde was found to be very toxic to the spores, only io per cent germinating after a six-minute exposure in a $\mathrm{x}$-to-500 solution, and 
30 per cent after a two-minute exposure in a 1 -to-250 solution, and only 75 per cent in a I-to-Ioo solution after one minute. Clark (3) found that I part by weight in 273,066 parts of water permitted the germination of but ro per cent of the spores of Oedocephalum albidum after II hours' exposure, as compared with 95 per cent after four hours in the controls, and greatly injured the mycelial development.

As regards the results, it should be stated that in all cases where the spores were not killed the germination was very much retarded. The colonies in the controls became visible to the naked eye in about 48 hours. A long exposure in a weak solution retarded germination to about the same degree that a short exposure in a correspondingly more concentrated solution. That the germination of Lima bean seeds is not injured by exposure for to minutes in the strongest solutions of mercuric chlorid, formaldehyde, and copper sulphate to which the spores were subjected is shown by a series of experiments discussed under "Control measures."

\section{CONTROL, MEASURES}

Halsted ( $I 7$ ) was the first, and probably the only one, who has ever done any experimental work on the control of the podblight of Lima beans. In these experiments spraying the dwarf Limas with Bordeaux mixture or soda-Bordeaux mixture yielded very favorable results. Although he evidently did not spray the pole Limas, he suggests that the disease could be checked by so doing. It is now known that the fungus attacks the leaves before the pods are set, and it is likely the pods become infected from them. In view of this fact, the first spraying should be done when the plants are I or 2 feet high, and should be repeated often enough to keep the foliage covered.

From badly infected pods the fungus invades the seed, where it may live for a considerable time. Infected seed are usually dark, shriveled, and immature. They probably would not grow, and, if they did, would give weak, sickly plants. Only plump, bright seed should be planted. Sound seed may be disinfected to kill the adhering spores by submerging for 5 or 10 minutes in a solution of mercuric chlorid ( 1 : 1,000 ), formaldehyde (I:I00), or copper sulphate ( $1: 100)$, after which they should be rinsed in water.

A series of experiments has shown that germination was not injured by such a treatment. Healthy Lima bean seeds were sorted out; a part were treated for 5 minutes and a part for Io minutes. After rinsing in sterile water, they were laid between moistened filter paper and germinated. The results showed that seeds exposed for so minutes gave just as good germination as those soaked in sterile water for the same length of time. It should be mentioned in this connection that those soaked in sterile water were all more or less covered with saprophytic molds, while those treated with mercuric chlorid, formaldehyde, and copper sulphate were comparatively free. 


\section{SUMMARY}

(I) The podblight of Lima beans is probably indigenous to the United States.

(2) It was first recognized by Halsted in New Jersey in I89I, and has since been found in the States of Virginia, Maryland, Connecticut, and North Carolina.

(3) The disease forms circular brown spots on the leaves, and large unsightly spots on the nearly mature pods and on the stems. Numerous pycnidia are produced in the diseased areas.

(4) The loss, which in some fields is very large, is confined mostly to the pods.

(5) The Lima bean podblight fungus has been known as Phoma subcircinata E. and E. almost since its first discovery, although in a few cases it has been referred to as a species of Phyllosticta.

(6) The writer isolated single ascospores of a Diaporthe found on specimens wintered out and made inoculations with pure cultures of such strains which produced a disease identical with that produced by inoculations with pure cultures of a pycnospore strain. In I892 Diaporthe phaseolorum was completely described, which agrees with the ascogenous fungus the writer has been studying. The fungus causing the disease is therefore referred to as Diaporthe phaseolorum (C. and E.) Sacc.

(7) The hyphæ course through and among the parenchymous cells of the pod, forming pycnidia just under the epidermis at points where the bast cells are more or less separated.

(8) Stylospores are abundantly found on field material and readily produced in culture on some media. The pycnospore stage belongs to the form genus Phomopsis and not to Phoma.

(9) The disease is readily produced by artificial inoculation with spores from both the pycnidial and ascogenous strains.

(Iо) Wounding of the pod is not necessary for infection, as the germ tubes may enter through the stomata.

(I I) The fungus is carried through from one season to the next, either by periodic production of pycnospores and the persistence of hyphæ or by the production of an ascospore stage.

(I2) The disease may be carried on the seed and spread by such agencies as wind, by the process of picking, and possibly by means of insects.

(I3) The fungus fruits well on stems of Melilotus alba, on rice, corn meal, and other starch media, and but poorly or not at all on the agars tried with the exception of corn-meal agar.

(I4) Cultures in the dark fruited more slowly than those in the light and had increased vegetative growth.

(I5) No growth takes place at a temperature below $6.1^{\circ}$ nor higher than $35 \cdot 4^{\circ} \mathrm{C}$. during a period of 27 days. 
(I6) Dilute solutions of formaldehyde, copper sulphate, and mercuric chlorid are toxic to the spores. The germination of the spores is greatly retarded when exposed to a solution too dilute to kill them in a given time.

(17) To control the podblight it is recommended that clean seed be selected. They should then be disinfected in mercuric chlorid, formalin, or copper sulphate. The plants should be sprayed in the field the first time when they are 1 to 2 feet tall, and often enough thereafter to keep the foliage covered.

(r) Brooks, Charles.

\section{LITERATURE CITED.}

I906. TEMPERATURE AND TOXIC ACTION. In Bot. Gaz., v. 42, no. 5, p. 359-375, I2 fig. Literature cited, p. 375 .

(2) BuBÁk, Franz, and KaBÁT, J. E.

I905. VIERTER BEITRAG ZUR PILZFLORA VON TIROL. In Österr. Bot. Ztschr. Jahrg. 55 , no. 2 , p. $73-79$. (Contizued article.)

(3) Clark, J. F.

I899. ON THE TOXIC EFFECT OF DELETERIOUS AGENTS ON THE GERMINATION AND DEVELOPMENT OF CERTAIN FILAMENTOUS FUNGI. In Bot. Gaz., v. 28 , no. 5 , p. $289-327$; no. 6 , p. $37^{8-404}$, Io diagr. Bibliography, p. $402-404$.

(4)

I9OI. ON THE TOXIC VALUE OF MERCURIC CHLORIDE AND ITS DOUBLE SALTS. In Jour. Phys. Chem., v. 5, no. 5, p. 289-3I6, 7 fig.

(5) Clinton, G. P.

I906. REPORT OF THE BOTANTST. NOTES ON FUNGUS DISEASES, ETC., FOR I905. In Conn. Agr. Exp. Sta., 29th Ann. Rpt., [1904]/05, p. 263-277.

(6) Coor, M. T.

I9I3. REPORT OF THE PLANT PATHOLOGist. In N. J. Agr. Exp. Sta., 33d Ann. Rpt., [IgII]/12, p. 509-527.

(7) IgI4. REPORT OF THE PLANT PATHOLOgist. In N. J. Agr. Exp. Sta., 34th Ann. Rpt., [1912]/13, p. 793-817, I3 fig.

(8) IgI5. REPORT OF THE PLANT PATHOLOGIST. In N. J. Agr. Exp. Sta., 35th Ann. Rpt., [1913]/14, p. 467-476.

(9) CookE, M. C., and ELLIS, J. B.

I878. NEW JERSEY FUNGI. In Grevillea, v. 6, no. 39, p. 8I-96. (Continued article.)

(ro) Coons, G. H.

I9I6. FACTORS INVOLVED IN THE GROWTH AND THE PYCNIDIUM FORMATION OF PlENodomus fuscomaculans. In Jour. Agr. Research, v. 5, no. I6, p. $713-769$. Literature cited, p. $766-769$.

(II) Coupin, $\mathrm{H}$.

IgOI. SUR LA SENSIBIEITÉ DES VÉGÉTAUX SUPÉRIEURS À DES DOSES TRES FAIBlES DE SUBSTANCES TOXIQUeS. In Compt. Rend. Acad. Sci. [Paris], t. 132, 10. 10, p. 645-647.

(12) Crandali, C. S. 1909. BORdeauX MiXture. Ill. Agr. Exp. Sta. Bul. I35, p. 199-296, 8 fig.

(I3) Diedicke, H. igir. Die gattung Phomorsis. In Ann. Mycol., Jahrg. 9, no. i, p. 8-35, 3 pl. 
(I4) EiLis, J. B., and Everhart, B. M.

1892. THE NORTH AMERICAN PYRENOMYCETES. 793 p., 4I pl. Newfield, N. J.

1894. NEW SPECIES OF NORTH AMERICAN FUNGI FROM VARIOUS LOCALITIES.

In Proc. Acad. Nat. Sci. Phila., I893, p. I28-I 72.

(I6) Halsted, B. D.

1892. LIMA BEAN DISEASES. In N. J. Agr. Exp. Sta., I2th Ann. Rpt., I8gi, p. 287 .

(I7)

I9OI. BEAN DISEASES AND THEIR REMEDIES. In N. J. Agr. Exp. Sta. Bul. I 5I, 28 p., $\theta$ fig., 4 pl.

(I8) HARTER, L. L.

1905. THE VARIABIIITY OF WHEAT VARIETIES IN RESISTANCE TO TOXIC SALTS. U. S. Dept. Agr. Bur. Plant Indus. Bul. 79, 48 p. Bibliography, p. $47-48$.

(I9) -

19I3. THE FOOT-ROT OF THE SWEET POTATO. In Jour. Agr. Research, v. I, no. 3, p. 25I-274, I fig., pl. 23-28.

(20)

I9I4. FRUIT-ROT, LEAF-SPOT, AND STEM BLIGHT OF THE EGG PLANT CAUSED BY PHomopsis vexans. In Jour. Agr. Research, v. 2, no. 5, p. 33I-338, I fig., pl. 26-30. Literature cited, p. $33^{8}$.

(2I) - and FIELD, Ethel C.

I9I3. A DRY ROT OF SWEET POTATOES CAUSED BY DIAPORTHE BATATATIS. U. S. Dept. Agr. Bur. Plant Indus. Bul. 28r, $3^{8}$ p., 4 fig., 4 pl.

(22) HEALD, F. D.

1896. ON THE TOXIC EFFECT OF DILUTE SOLUTIONS OF ACIDS AND SALTS UPON PLANTS. In Bot. Gaz., v. 22, no. 2, p. I25-153, pl. 7.

(23) HöHNEL, Franz von.

1903. MYCOLOGISCHE FRAgmente. In Ann. Mycol., Jahrg. I, no. 5, p. 39I$4 \mathrm{r} 4$; no. 6, p. 522-534.

(24) JoNES, L, R.

r896. REPORT OF THE BOTANIST. In Vt. Agr. Exp. Sta., 9th Ann. Rpt., I895, p. 66-I I5, I5 fig.

(25) Giddings, N. J., and Lutman, B. F.

I912. INVESTIGATIONS OF THE POTATO FUNGUS, PHYTOPHTHORA INFESTANS. Vt. Agr. Exp. Sta. Bul. I68, roo p., Io fig., ro pl. Index to literature, p. 88-93.

(26) Moore, G. T., and KeLLERMAN, K. F.

I904. A METHOD OF DESTROYING OR PREVENTING THE GROWTH OF ALGAE AND CERTAIN PATHOGENIC BACTERIA IN WATER SUPPLIES. U. S. Dept. Agr. Bur. Plant Indus. Bul. 64,44 p.

(27) Pool, Venus W., and McKay, M. B.

I9I5. PHOMA BETAE ON THE I.EAVES OF THE SUGAR BEET. In Jour. Agr. Research, v. 4, no. 2 , p. 169-177, pl. 27 .

I9I6. RELATION OF STOMATAL MOVEMENT TO INFECTION BY CERCOSPORA BETICor.A. In Jour. Agr. Research, v. 5, no. 22, p. IоII-I038, 6 fig., pl. 80-8I. Literature cited, p. 1038.

(29) REDDICK, Donald.

I909. Necrosis of the grapevine. N. Y. (Cornell) Agr. Exp. Sta. Bul. 263, p. $323-343$, fig. 4 I -57 . 
(30) Saccardo, P. A.

1879. FUNGI VENETI NOVI VEL CRITICI VEL IYYCOLOGIAE VENETAE ADDENDI, SERIES VII. In Michelia, v. I, no. 2, p. I33-221.

(3I)

I879. SYLLOGE FUNGORUM. v. I8. Patavii.

(32) SHEAR, C. L.

IgII. THE ASCOGENOUS FORM OF THE FUNGUS CAUSING DEADARM OF THE GRAPE. In Phytopathology, v. I, no. 4, p. I I6-II9, 5 fig.

(33) Sмiтн, C. O.

1905. THE STUDY OF THE DISEASES OF SOME TRUCK CROPS IN DELAWARE. Del. Agr. Exp. Sta. Bul. 70, 16 p., 6 fig., 2 pl.

(34) STEWART, V. B.

IgI6. THE LEAF BLOTCH DISEASE OF HORSECHESTNUT. In Phytopathology, v. 6, no. I, p. 5-19, I fig., pl. 2-4 (part. col.).

\section{PLATE 42}

\section{Diaporthe phaseolorum:}

A.-A leaflet of Phaseolus lunatus L., showing a number of ragged holes of various sizes caused by the Lima bean podblight fungus. This specimen was collected at Cape May, N. J., August 5, I9I5. The disease was produced on pods by inoculation with the organism (6or) isolated from this leaf. Natural size.

B.-A green Lima bean pod photographed ro days after inoculation with the ascospore strain. Pycnidia are abundantly formed over an area about $1 / 2$ inch in diameter; outside of this is another somewhat darkened area which has already been invaded by the fungus, but the pycnidia have not yet broken through the epidermis. Natural size.

C.-A pod showing the characteristic manner in which the fungus rapidly overruns it soon after it is killed, pycnidia forming indiscriminately over the entire surface. Natural size. 

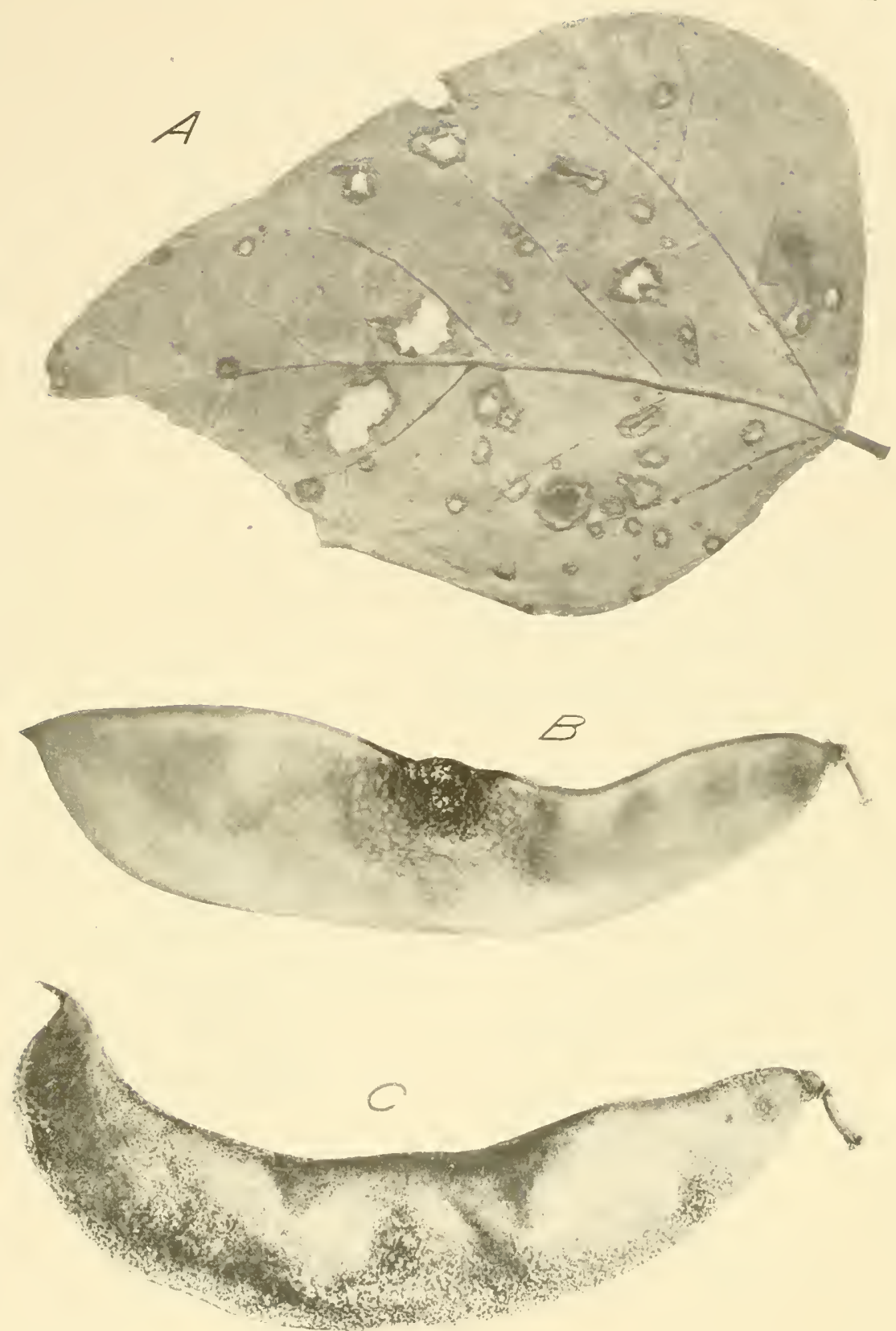

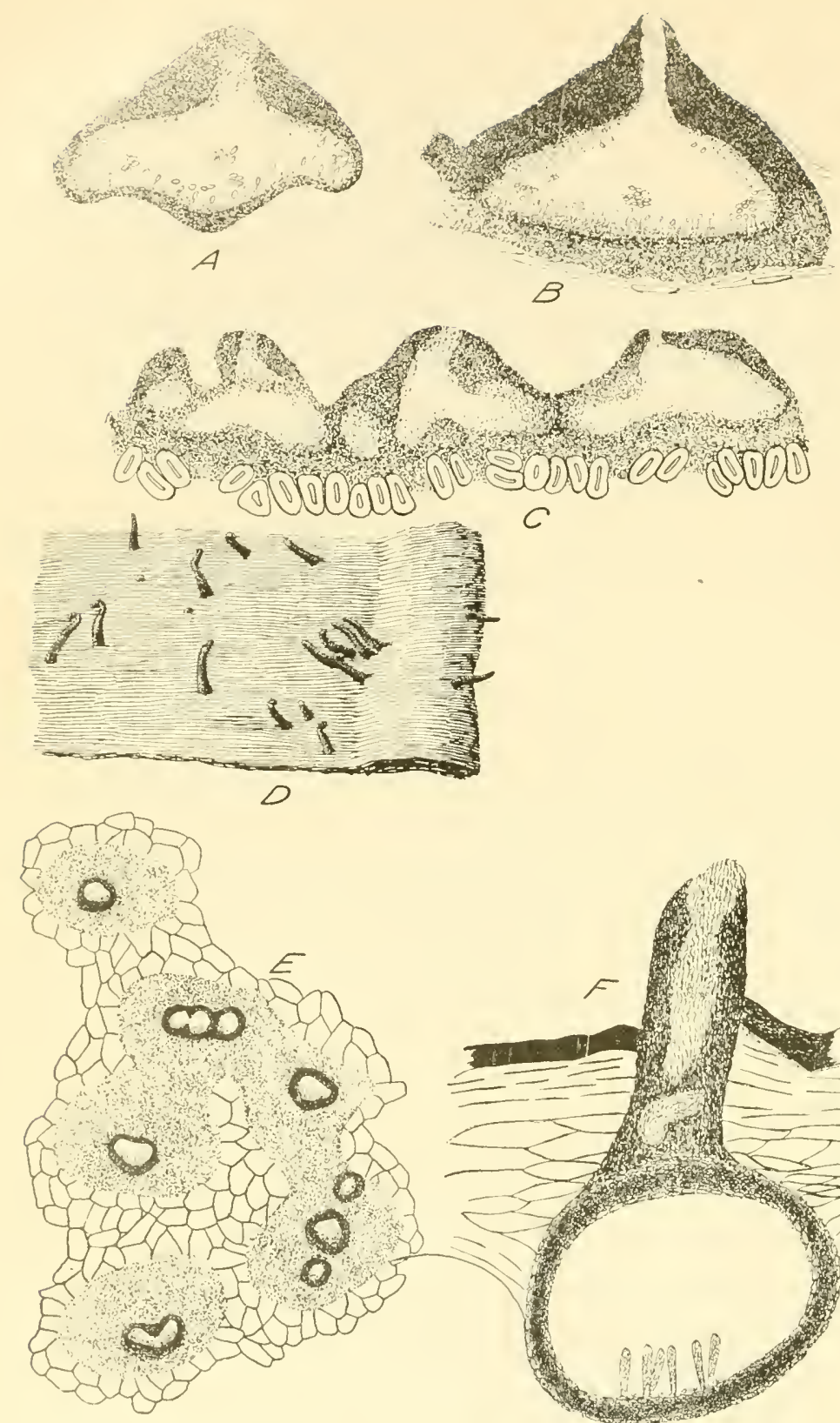

Journal of Agricultural Research

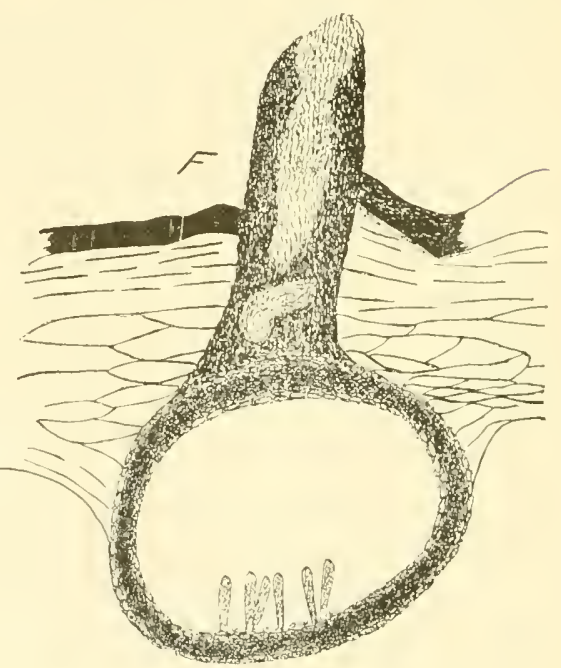




\section{PLATE 43}

Diaporthe phaseolorum:

A.-A vertical section through a pycnidium from the leaf. $X_{\mathbf{I} 30}$

B.-A vertical section through a pycnidium from a pod showing the beak and the thickened dark wall surrounding it. Note also conidiophores arising from hyalin inner ayer. Some spores are attached. $\times_{\mathbf{I}} 3$.

C. - A vertical section through the epidermis and underlying host of a portion of a diseased pod showing the connection and chambering of the pycnidia. $\times 65$.

D.-A somewhat diagrammatic drawing of a portion of the surface of a Lima bean pod, showing the distribution of the perithecia, the shape of the beaks and their projection from the surface. The beaks of two perithecia may be seen just breaking through the epidermis. $\times I 6$.

E.-A surface view of a portion of a bean pod showing arrangement of the pycnidia and fusion of the beaks. $\times 65$.

F.-A vertical section through a perithecium from a pod. Note the dark wall surrounding the perithecium in which the asci are inclosed; also the portion of the beak buried below the surface of the pod." The outer end of the beak has been cut away. $\times$ זзо. 





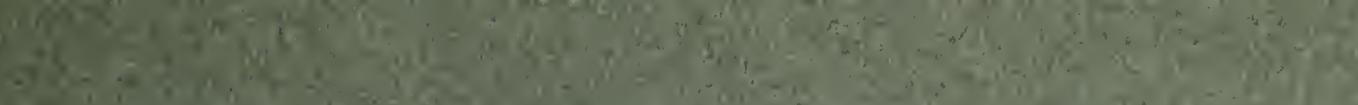

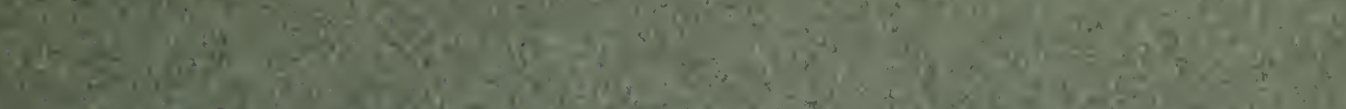
Sy.

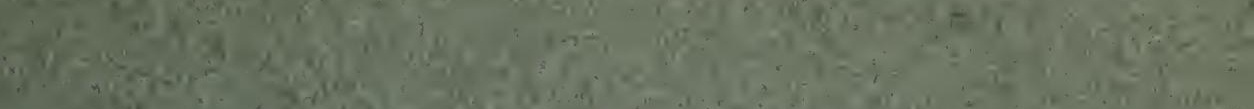

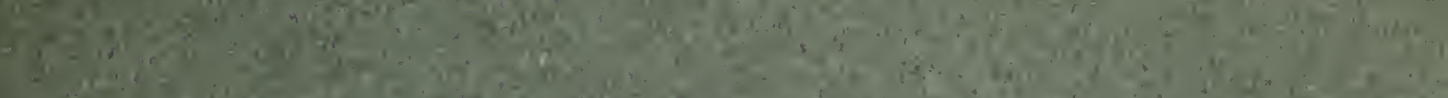

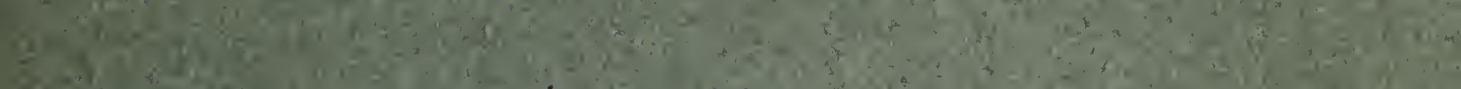

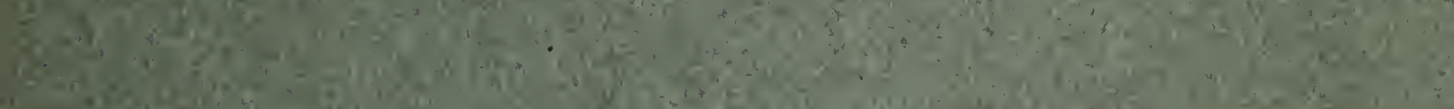
3.

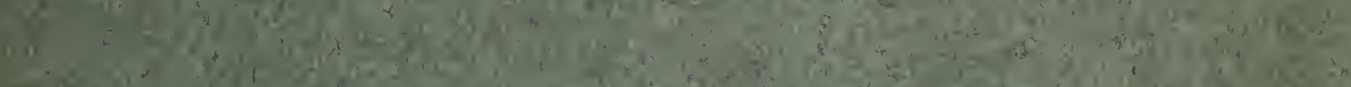

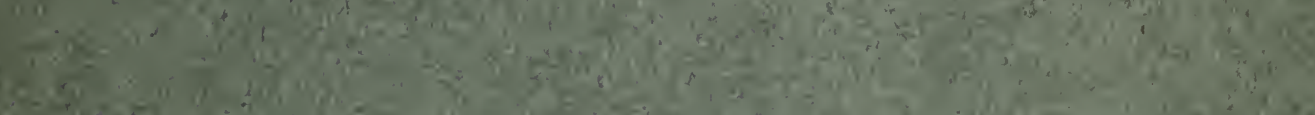
A

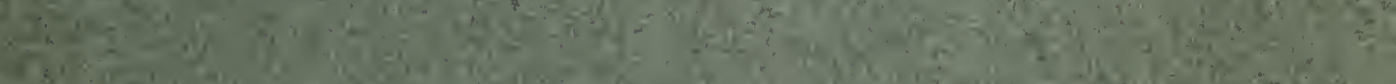

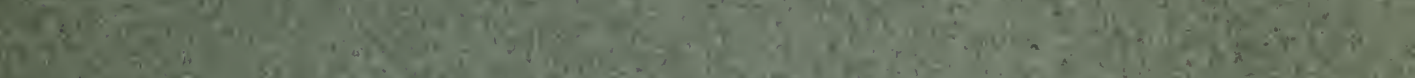

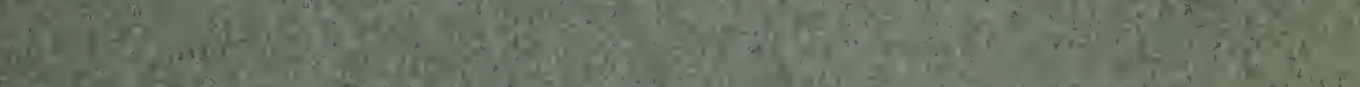

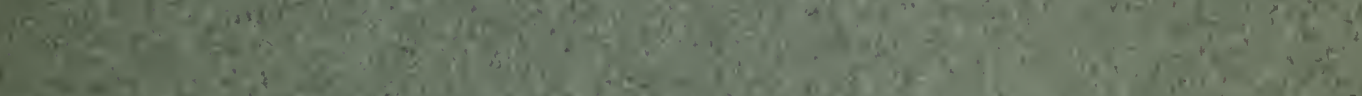

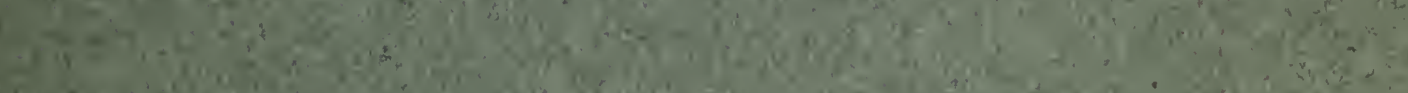

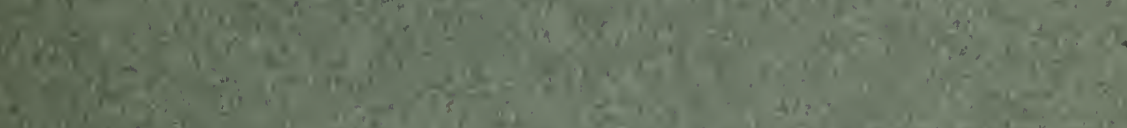

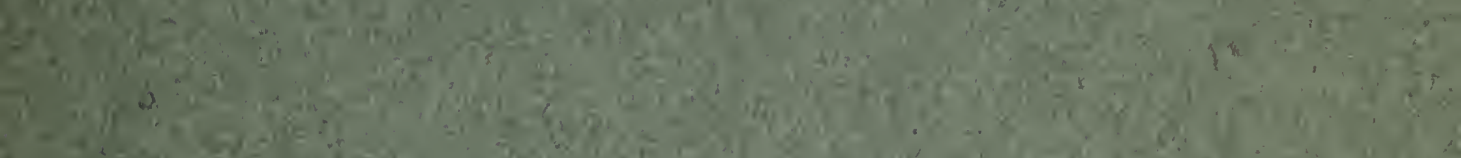

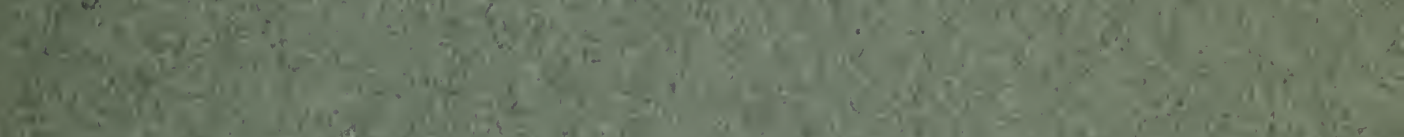

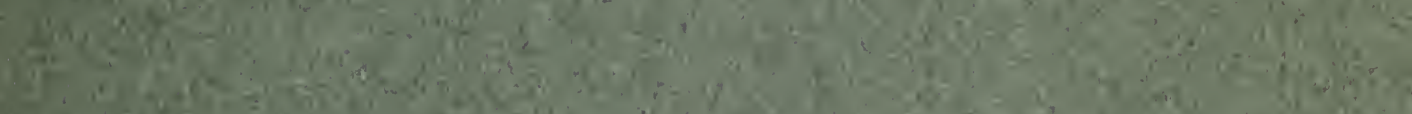

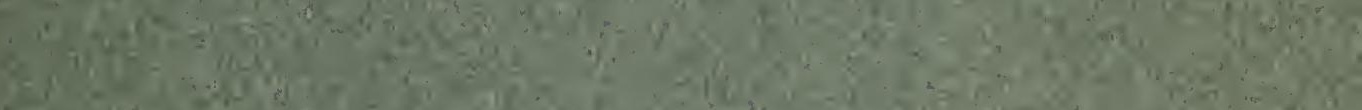

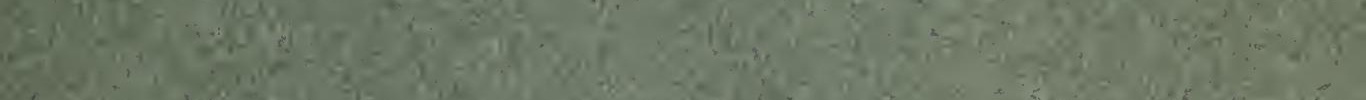

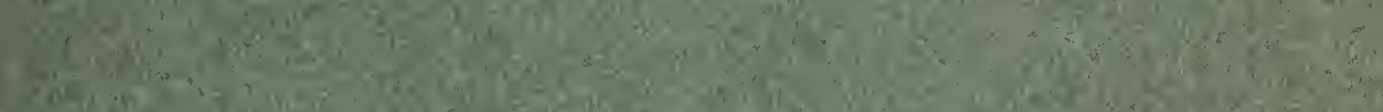

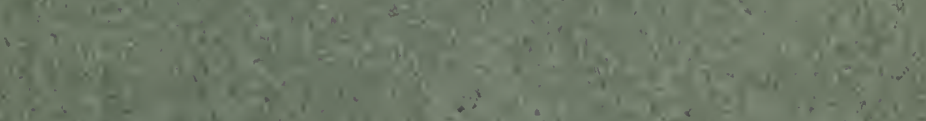
a.

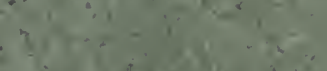

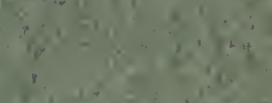

b.

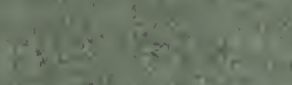

Cof (1.60,

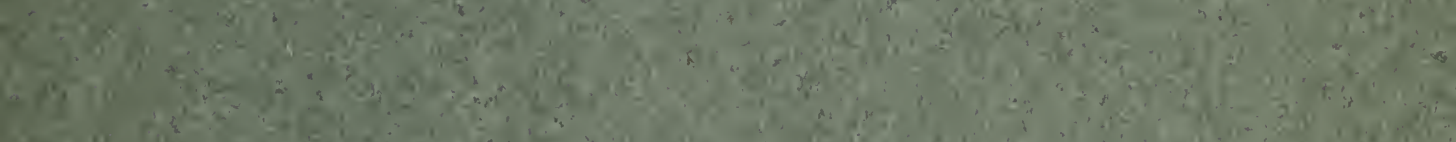

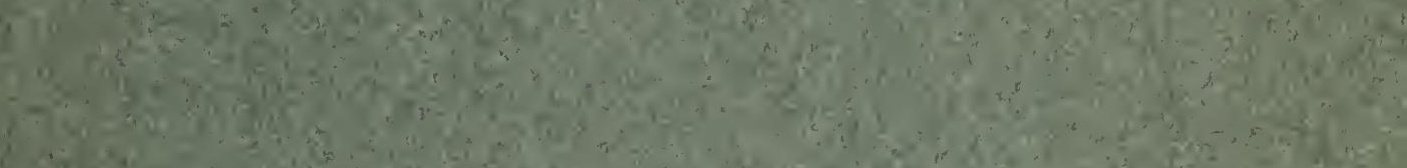

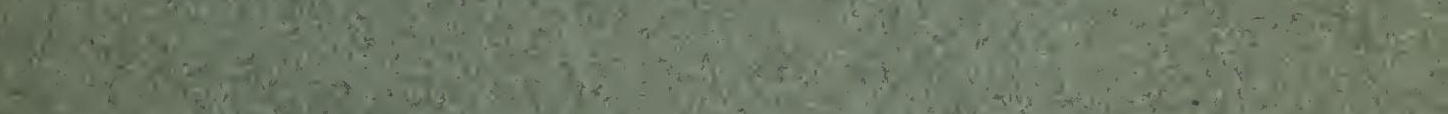

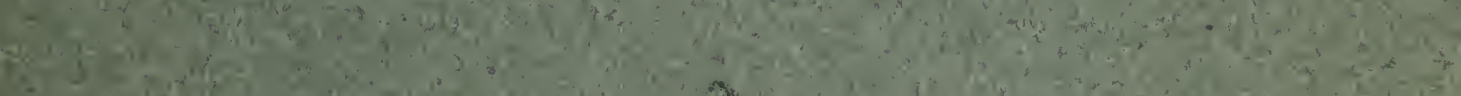

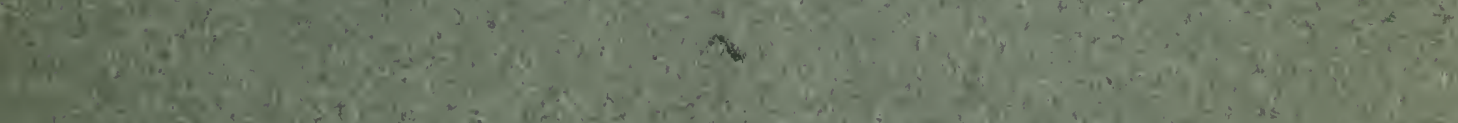

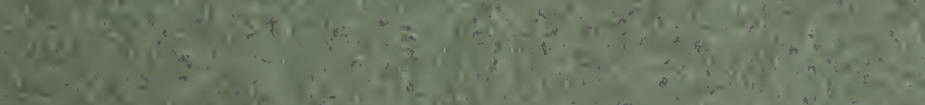
tof

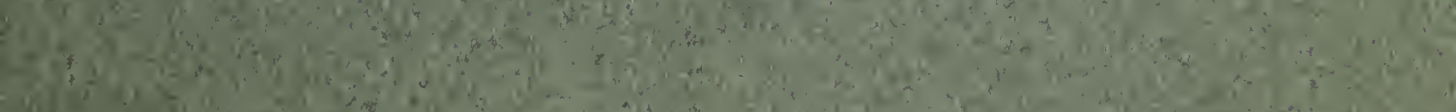


